\title{
Mechanistic Studies on the Catalytic Oxidative Amination of Alkenes by Rhodium(I) Complexes with Hemilabile Phosphines
}

\author{
M. Victoria Jiménez,* M. Isabel Bartolomé, Jesús J. Pérez-Torrente,* Daniel Gómez, F. Javier \\ Modrego, and Luis A. Oro ${ }^{[a]}$
}

\begin{abstract}
Cationic rhodium(I) complexes having $\mathrm{P}, \mathrm{O}$-functionalized arylphosphine ligands are efficient catalysts for the regioselective antiMarkovnikov oxidative amination of styrene with piperidine. The mechanism of the catalytic reaction has been investigated by spectroscopic means under stoichiometric and catalytic conditions. In the presence of piperidine the catalyst precursor $\left[\mathrm{Rh}\left\{\kappa^{2}-\mathrm{P}, \mathrm{O}-\mathrm{Ph}_{2} \mathrm{P}\left(\mathrm{CH}_{2}\right)_{3} \mathrm{OEt}\right\}_{2}\right]^{+}$ gives the piperidine complex $\left[\mathrm{Rh}\left\{\kappa^{1}-\mathrm{P}\right.\right.$ $\left.\left.\mathrm{Ph}_{2} \mathrm{P}\left(\mathrm{CH}_{2}\right)_{3} \mathrm{OEt}\right\}_{2}\left(\mathrm{HNC}_{5} \mathrm{H}_{10}\right)_{2}\right]^{+}(\mathbf{8})$ that was transformed into the neutral amidopiperidine species $\quad\left[\mathrm{Rh}\left\{\kappa^{1}-\mathrm{P}\right.\right.$ $\left.\left.\mathrm{Ph}_{2} \mathrm{P}\left(\mathrm{CH}_{2}\right)_{3} \mathrm{OEt}\right\}_{2}\left(\mathrm{NC}_{5} \mathrm{H}_{10}\right)\left(\mathrm{HNC}_{5} \mathrm{H}_{10}\right)\right]$ (9) under thermal conditions. NMR
\end{abstract}

studies carried out in the presence of styrene under catalytic conditions showed that $\mathbf{9}$ is a key species in the catalytic oxidative amination of styrene. Related cyclooctadiene-containing catalyst precursors $\left[\mathrm{Rh}(\operatorname{cod})\left\{\kappa^{1}-\mathrm{P}-\right.\right.$ $\left.\left.\mathrm{Ph}_{2} \mathrm{P}\left(\mathrm{CH}_{2}\right)_{3} \mathrm{OEt}\right\}_{\mathrm{n}}\right]^{+}(\mathrm{n}=1,2)$ also gave 9 under the same conditions. The proposed catalytic cycle has been established by a series of DFT calculations including the transition states of the key steps that have been found and characterized. These studies have shown that, after the elimination of the enamine, the regeneration of catalytic active species takes place by direct transfer of the proton of a piperidine ligand to the alkyl group, resulting from the insertion of styrene into $\mathrm{Rh}-\mathrm{H}$ bond, with formation of ethylbenzene. Against the expectations, the formation of a dihydride intermediate by $\mathrm{NH}$ oxidative addition is a highly energy-demanding process. Catalyst $\mathbf{5}$ has also been applied for the oxidative amination of substituted vinylarenes with several secondary cyclic and acyclic amines.

Keywords: oxidative amination .
homogeneous catalysis - reaction
mechanism - rhodium . density
functional calculations

\section{Introduction}

The direct addition of ammonia, primary or secondary amines to alkenes affords amines, products of the formal N-H bond addition to the unsaturated carbon-carbon bond, or enamines as a result of an oxidative amination. ${ }^{1}$ Both product classes are highly valuable building blocks in fine chemical synthesis, and particularly amines are also of great relevance for bulk chemicals synthesis. The intermolecular hydroamination is an efficient alternative to the classic organic synthesis procedures for the preparation of nitrogen-containing compounds. However, the uncatalysed reactions have very high-energy barriers thereby requiring the use of a catalyst. In spite of the rapid development of the catalysed intramolecular aminations methods to produce cyclic aminoalkanes or aminoalkenes, the intermolecular hydroaminations/oxidative amination has experienced less progress, and in particular, the antiMarkovnikov functionalization of unactivated olefins with amines still remains a challenge in catalysis. In this context, mechanistic studies are of key importance for the development of efficient catalyst to achieve this important goal.

The general mechanisms commonly accepted for lanthanide ${ }^{1,2}$ or group 4 metal hydroamination catalysts ${ }^{3}$ are the migratory

[a] Dra. M. Victoria Jiménez, Dra. M. Isabel Bartolomé, Prof. Dr. Jesús J. PérezTorrente, Ldo. Daniel Gómez, Dr. F. Javier Modrego, and Prof. Dr. Luis A. Oro

Departamento de Química Inorgánica, Instituto de Síntesis Química y

Catálisis Homogénea, Universidad de Zaragoza-C.S.I.C., 50009-Zaragoza,

Spain.

E-mail: vjimenez@unizar.es,perez@unizar.es.

Supporting information for this article is available on the WWW under http://www.chemeurj.org/ or from the author. insertion of the alkene into a metal-amide species followed by proton transfer, ${ }^{4}$ and the $[2+2]$ addition of alkenes and metalimido intermediates. ${ }^{1 \mathrm{~b}, 5}$ On the other hand, two comprehensive mechanisms have been described for late transition metals based hydroamination catalyst (Figure 1): the nucleophilic attack at the coordinated alkene (olefin activation) and the oxidative addition of the amine on the metal centre, followed by olefin insertion into the metal-amide bond (amine activation).

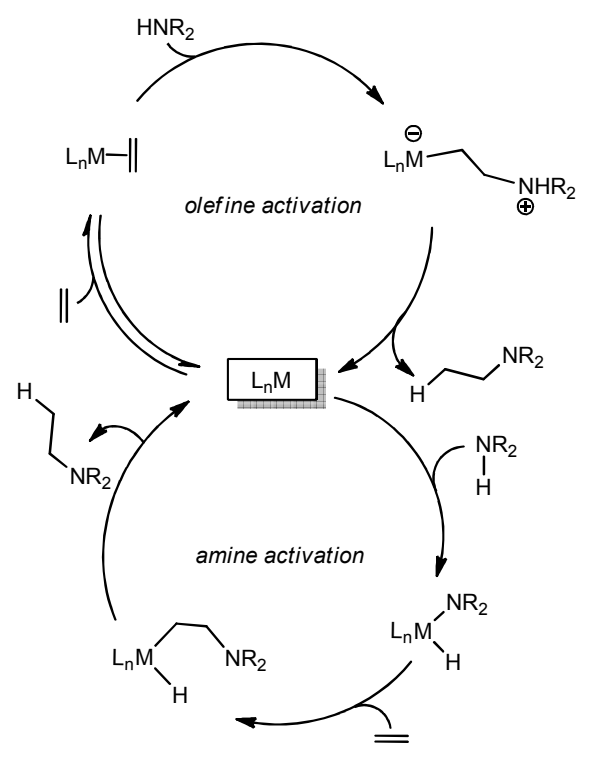

Figure 1. Mechanisms for late transition metal based hydroamination catalysts.

The key step of the first mechanistic model is the activation of the alkene by coordination to a Lewis acidic metal centre, which 
renders the $\pi$-system susceptible to nucleophilic attack by the amine. Subsequent protolytic cleavage of the metal-carbon bond in the zwitterionic 2-ammonium-alkyl complex affords the amine product after decoordination from the metal centre. Interestingly, several experimental findings on late transition metal catalysed hydroamination supporting this mechanism have been recently reported, for both intermolecular ${ }^{6}$ and intramolecular versions. ${ }^{7}$

On the other hand, the activation of the amine by oxidative addition to a coordinatively unsaturated late transition metal in low oxidation state has been proposed often as a potential pathway for hydroamination catalysed by ruthenium(0), rhodium(I), iridium(I), copper(I), palladium(0) or platinum(0) metal complexes. The oxidative addition of the amine results in the formation of a hydrido-amido intermediate. Subsequently, insertion of the alkene into the $\mathrm{M}-\mathrm{N}$ or $\mathrm{M}-\mathrm{H}$ bond followed by reductive elimination affords the amine product and regenerates the active metal species (Figure 1). Although the N-H bond activation has been postulated as the first step in the mechanism, there are only a few examples of direct formation of amido complexes from amines, most of them in iridium complexes. ${ }^{8,9}$ Migratory insertion of alkenes into the M$\mathrm{NR}_{2}$ bond is a favourable process in late transition metal complexes. In fact, theoretical calculations for the migratory insertion of the alkene in complexes $\left[\left(\mathrm{PMe}_{3}\right)_{2} \mathrm{Rh}\left(\eta^{2}\right.\right.$-alkene $\left.)\left(\mathrm{NH}_{2}\right)\right]$ evidenced low energy barriers, even lower than the found for the migratory insertion into a $\mathrm{Rh}-\mathrm{CH}_{3}$ bond. ${ }^{10}$ Similar results have been reported for group 10 hydrido-amido metal complexes $\left[\mathrm{MH}\left(\mathrm{NR}_{2}\right)\left(\mathrm{PEt}_{3}\right)_{2}\right](\mathrm{M}=\mathrm{Pd}, \mathrm{Pt})$ where the insertion of alkenes into the $\mathrm{M}-\mathrm{NR}_{2}$ bond is preferred over the insertion into the $\mathrm{M}-\mathrm{H} .{ }^{11}$ Finally, the last step of the catalytic cycle leading to the amine product is the reductive elimination. ${ }^{12}$ However, the reductive elimination competes with the $\beta$-hydride elimination that results in the formation of the enamine product (oxidative amination) being necessary in this case a hydrogen acceptor to regenerate the active species. The oxidative amination products were first observed by Brunet in the hydroamination of styrene with aniline catalysed by the system $\left[\mathrm{RhCl}\left(\mathrm{PEt}_{3}\right)_{2}\right]_{2} / \mathrm{LiPhNH}$ that mainly affords the Markovnikov hydroamination compound, N-(1-phenylethyl)aniline, in a regioselective way. ${ }^{13}$

We have recently found that rhodium(I) complexes containing hemilabile phosphine ligands of the type $\mathrm{Ar}_{2} \mathrm{P}\left(\mathrm{CH}_{2}\right)_{\mathrm{n}} \mathrm{Z}(\mathrm{Z}=\mathrm{OR}$, $\left.\mathrm{NR}_{2}, \mathrm{SR} ; \mathrm{n}=2,3\right)$ are active catalysts for the regioselective antiMarkovnikov oxidative amination of styrene with piperidine. ${ }^{14,15}$ Interestingly, the catalyst containing P,O-functionalized arylphosphine ligands having a 3-alkoxypropyl hemilabile moiety, $\mathrm{Ar}_{2} \mathrm{P}\left(\mathrm{CH}_{2}\right)_{3} \mathrm{OR}(\mathrm{R}=\mathrm{Me}, \mathrm{Et}, \mathrm{nBu})$, exhibited a higher catalytic activity than those containing $\mathrm{P}, \mathrm{N}$-functionalized phosphine ligands. Important features of these flexible ligands are their potential for a weak interaction with the rhodium centre through the oxygen atom forming a six-membered metallocycle ring. In spite that each single reaction step of the generally accepted mechanism appears feasible, ${ }^{1}$ the reaction pathway, both for the catalytic hydroamination and oxidative amination, still remains ambiguous with regard to the initial oxidative addition of the amine. ${ }^{16}$ In the present work, we have been particularly interested in determining the reaction mechanism to provide a basis for the design of improved catalysts. Thus, mechanistic studies under both stoichiometric and catalytic conditions have been carried out. In addition, a plausible catalytic cycle and a potential role of the ether-functionalized phosphine ligands have been established by DFT calculations.

\section{Results and Discussion}

Rhodium complexes with hemilabile phosphines as efficient catalysts for oxidative amination
Cationic rhodium(I) complexes containing $\mathrm{P}, \mathrm{O}$-functionalized arylphosphine ligands have shown an outstanding catalytic activity for the regioselective anti-Markovnikov oxidative amination of styrene with piperidine, a benchmark reaction for the intermolecular alkene hydroamination. ${ }^{14,15}$ In particular, complexes having arylphosphine ligands with a 3-ethoxypropyl hemilabile moiety exhibited a superior catalytic activity. ${ }^{17}$

Table 1. Oxidative amination of styrene with piperidine catalysed by complexes $\left[\mathrm{Rh}(\mathrm{cod})_{\mathrm{n}}\left\{\mathrm{Ar}_{2} \mathrm{P}\left(\mathrm{CH}_{2}\right)_{3} \mathrm{OEt}\right\}_{\mathrm{m}}\right] \mathrm{BF}_{4}(\mathrm{n}=0,1, \mathrm{~m}=1,2) .{ }^{[\mathrm{l}]}$

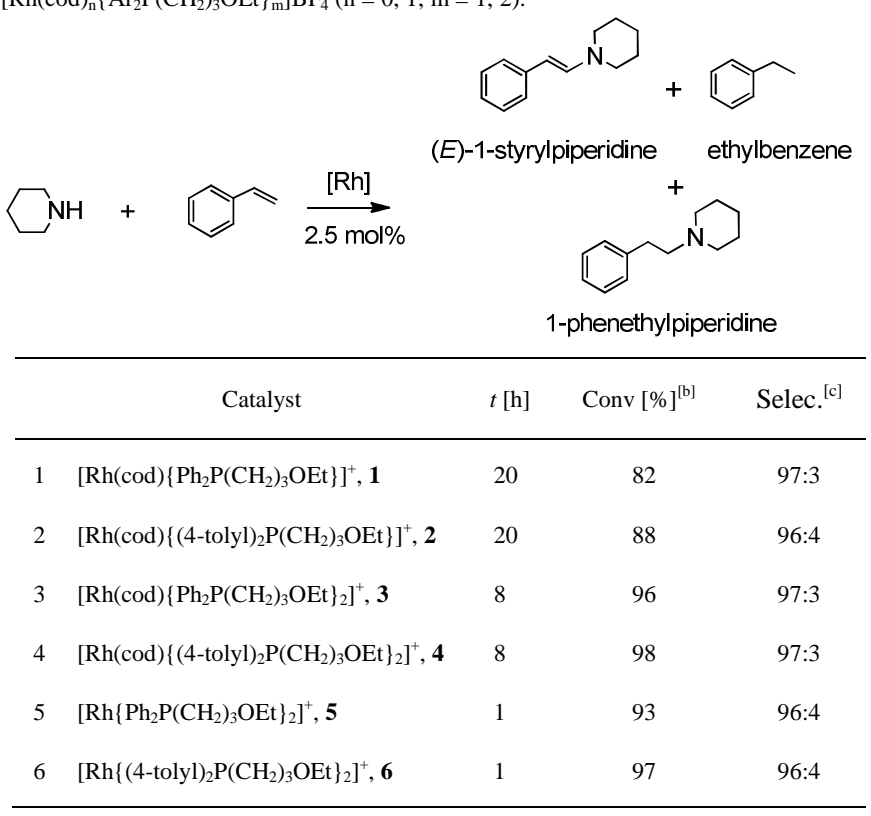

[a] Reaction conditions: styrene (4 mmol), piperidine $(1 \mathrm{mmol})$, solvent $(2.5 \mathrm{~mL})$, $[\mathrm{Rh}]=0.01 \mathrm{M}$ in $\operatorname{THF}(2.5 \mathrm{~mol} \%), 80^{\circ} \mathrm{C}$. [b] Standard conditions of analysis. Conversion relative to piperidine $(\%)$ determined by GC analysis using tetradadecane as internal standard. [c] Selectivity: (E)-1-styrylpiperidine/1-phenethylpiperidine ratio.

We have observed that the catalyst structure has a strong influence on the catalytic activity (Table 1). In fact, complexes featuring two $\kappa^{1}-\mathrm{P}$ coordinated hemilabile ligands, $\left[\mathrm{Rh}(\mathrm{cod})\left\{\mathrm{Ar}_{2} \mathrm{P}\left(\mathrm{CH}_{2}\right)_{3} \mathrm{OEt}\right\}_{2}\right]^{+}(\mathrm{Ar}=\mathrm{Ph}, \mathbf{3} ; \mathrm{Ar}=4$-tolyl, 4), exhibited higher catalytic activity than the complexes $\left[\mathrm{Rh}(\mathrm{cod})\left\{\mathrm{Ar}_{2} \mathrm{P}\left(\mathrm{CH}_{2}\right)_{3} \mathrm{OEt}\right\}\right]^{+}(\mathrm{Ar}=\mathrm{Ph}, \mathbf{1} ; \mathrm{Ar}=4$-tolyl, 2) having only one hemilabile ligand $\kappa^{2}-\mathrm{P}, \mathrm{O}$ coordinated (entries 1-4). Interestingly, bisphosphine complexes $\left[\mathrm{Rh}\left\{\mathrm{Ar}_{2} \mathrm{P}\left(\mathrm{CH}_{2}\right)_{3} \mathrm{OEt}\right\}_{2}\right]^{+}$, with two $\mathrm{K}^{2}-\mathrm{P}, \mathrm{O}$ coordinated ligands with a cis disposition $(\mathrm{Ar}=$ $\mathrm{Ph}, 5 ; \mathrm{Ar}=4$-tolyl, 6), showed an outstandingly high catalytic activity (entries 5 and 6). The best catalytic performance was observed with catalyst $\left[\mathrm{Rh}\left\{(4-\text { tolyl })_{2} \mathrm{P}\left(\mathrm{CH}_{2}\right)_{3} \mathrm{OEt}\right\}_{2}\right]\left[\mathrm{PF}_{6}\right]$ (6) giving turnover frequencies up to $85 \mathrm{~h}^{-1}$ with excellent enamine selectivity $(96 \%) .{ }^{18}$

\section{Activation of the precatalyst}

The cationic complexes $\left[\mathrm{Rh}\left\{\mathrm{Ph}_{2} \mathrm{P}\left(\mathrm{CH}_{2}\right)_{3} \mathrm{OEt}\right\}_{2}\right]^{+}$(5) and $\left[\mathrm{Rh}\left\{(4 \text {-tolyl })_{2} \mathrm{P}\left(\mathrm{CH}_{2}\right)_{3} \mathrm{OEt}\right\}_{2}\right]^{+},(\mathbf{6})$ are reactive species. In fact, both compounds quickly reacted with piperidine to give piperidine complexes as result of the decoordination of the hemilabile fragment of the functionalized phosphine ligands. The addition of one equiv. of piperidine to a solution of $\mathbf{5}$ in THF- $d_{8}$ at room temperature gave the compound $\left[\mathrm{Rh}\left\{\mathrm{Ph}_{2} \mathrm{P}\left(\mathrm{CH}_{2}\right)_{3} \mathrm{OEt}\right\}_{2}\left(\mathrm{HNC}_{5} \mathrm{H}_{10}\right)\right]^{+}$(7) with $\kappa^{1}-\mathrm{P}$ and $\kappa^{2}-\mathrm{P}, \mathrm{O}$ coordinated ligands (Scheme 1). Compound $\mathbf{7}$ is fluxional as it was evidenced in the ${ }^{31} \mathrm{P}\left\{{ }^{1} \mathrm{H}\right\}$ NMR spectrum at $298 \mathrm{~K}$ that showed two broad resonances at $\delta \approx 51$ and $33 \mathrm{ppm}$. However, the ${ }^{31} \mathrm{P}\left\{{ }^{1} \mathrm{H}\right\}$ 
NMR spectrum at $253 \mathrm{~K}$ consists of two doublet of doublets at $\delta$ $50.24\left(J_{\mathrm{P}-\mathrm{Rh}}=215.0\right)$ and $30.23 \mathrm{ppm}\left(J_{\mathrm{P}-\mathrm{Rh}}=161.0\right)$ with a $J_{\mathrm{P}-\mathrm{P}}$ coupling constant of $54.4 \mathrm{~Hz}$ (Figure 2), in full agreement with the proposed structure. The reaction of $\mathbf{5}$ with an excess of piperidine (1:40) in THF- $d_{8}$ gave $\left[\mathrm{Rh}\left\{\mathrm{Ph}_{2} \mathrm{P}\left(\mathrm{CH}_{2}\right)_{3} \mathrm{OEt}\right\}_{2}\left(\mathrm{HNC}_{5} \mathrm{H}_{10}\right)_{2}\right]^{+}$(8). Complex 8 is also fluxional, but at $253 \mathrm{~K}$ the ${ }^{31} \mathrm{P}\left\{{ }^{1} \mathrm{H}\right\}$ NMR spectrum (figure 2$)$ showed a sharp doublet at $\delta 38.29 \mathrm{ppm}\left(J_{\mathrm{P}-\mathrm{Rh}}=\right.$ $170.2 \mathrm{~Hz}$ ) what is in accordance with a symmetric molecule having two piperidine ligands and two ether-phosphine ligands $\kappa^{1}-P$ coordinated with a cis disposition. Compounds $\mathbf{7}$ and $\mathbf{8}$ could not be isolated in the solid state and were characterized in solution at low temperature. Both species are in equilibrium as it was shown by a ${ }^{31} \mathrm{P}\left\{{ }^{1} \mathrm{H}\right\}$ NMR study at variable temperature on a THF- $d_{8}$ solution of $\mathbf{5}$ and two equiv. of piperidine (Hpip).
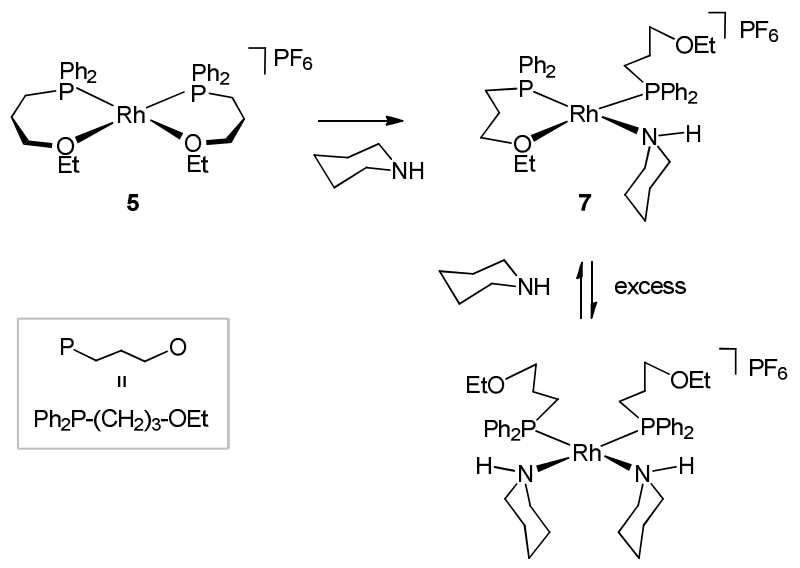

8

Scheme 1. Sequential formation of piperidine complexes from 5.
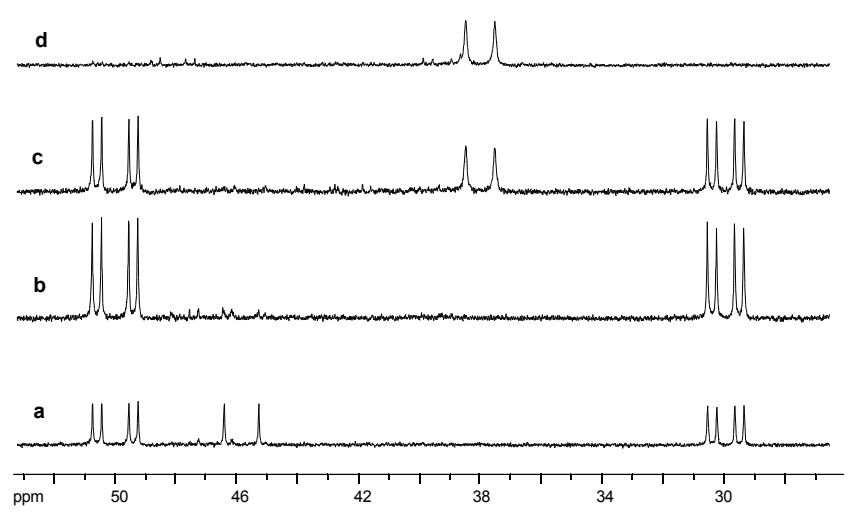

Figure 2. ${ }^{31} \mathrm{P}\left\{{ }^{1} \mathrm{H}\right\}$ NMR (THF- $d_{8}, 253 \mathrm{~K}$ ) for the reaction $\left[\mathrm{Rh}\left\{\mathrm{Ph}_{2} \mathrm{P}\left(\mathrm{CH}_{2}\right)_{3} \mathrm{OEt}\right\}_{2}\right]\left[\mathrm{PF}_{6}\right]$ (5) with piperidine. a) 5 with 0.8 eq. piperidine; b) 5 with 1 eq. piperidine; c) 5 with 2 eq. piperidine; d) 5 with 40 eq. piperidine.

As can be seen in Figure 3, the equilibrium is shifted to $\mathbf{8}$ at temperatures down $178 \mathrm{~K}$. Increasing the temperature results in the formation of $\mathbf{7}$ as a consequence of the equilibrium displacement. The calculated equilibrium constant at $273 \mathrm{~K}$ is $\mathrm{K}=2.62$. The thermodynamic parameters estimated from the Van't Hoff representations ( $\mathrm{Ln} \mathrm{K} \mathrm{vs} \mathrm{1/T)} \mathrm{in} \mathrm{the} \mathrm{temperature} \mathrm{range} \mathrm{193-288} \mathrm{K}$ were $\Delta \mathrm{H}^{\circ}=6,9 \pm 0,4 \mathrm{kcal} \mathrm{mol}^{-1}$ and $\Delta \mathrm{S}^{\circ}=29,0 \pm 1,7 \mathrm{cal} \mathrm{K}^{-1} \mathrm{~mol}^{-1}$ (Supporting information). DFT calculation on these species have shown that both complexes $\mathbf{7}$ and $\mathbf{8}$ are more stable than $\mathbf{5}$ by -7.2 and $-19.6 \mathrm{Kcal} \mathrm{mol}^{-1}$, respectively, which is in full agreement with the thermodynamic calculated data. The optimized structure of $\mathbf{8}$ has revealed a long range interaction (ca. $4 \AA$ ) between the oxygen atom of an ethoxy group and the $\mathrm{NH}$ of one of the piperidine ligands. However, several conformers of both complexes having an hydrogen bond ( $c a$. $2.9 \AA$ ) are only slightly higher in energy (less than $4 \mathrm{Kcal} \mathrm{mol}^{-1}$ ). which could be in part, responsible for the enhanced stability of $\mathbf{8}$ over $\mathbf{7}$.
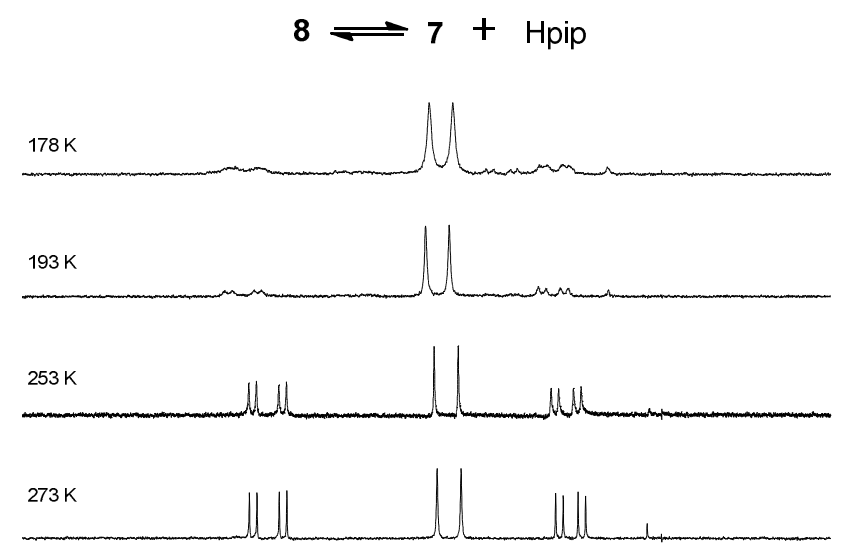

$298 \mathrm{~K}$

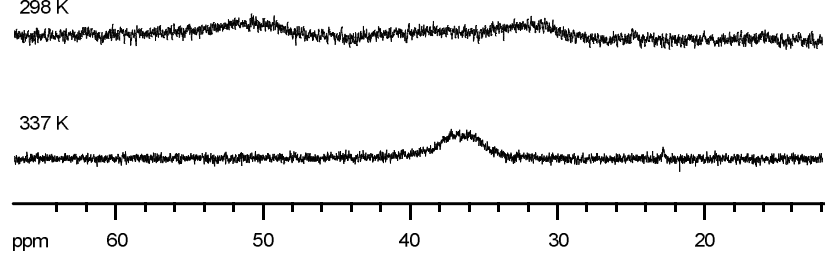

Figure 3. Variable temperature ${ }^{31} \mathrm{P}\left\{{ }^{1} \mathrm{H}\right\}$ NMR $\left(\right.$ THF- $\left.d_{8}\right)$ study for the reaction of $\mathbf{5}$ with 2 eq. of Hpip (piperidine).

When a mixture of the piperidine compounds $\mathbf{7}$ plus $\mathbf{8}$, obtained by reaction of $\mathbf{5}$ with a slight excess of piperidine (1:3) in THF- $d_{8}$, was heated at $343 \mathrm{~K}$ for $2 \mathrm{~h}$, the clean formation of the new specie 9 was observed. The ${ }^{31} \mathrm{P}\left\{{ }^{1} \mathrm{H}\right\}$ NMR at room temperature, consists in two doublet of doublets at $\delta 39.60$ and $36.31 \mathrm{ppm}$ with $J_{\mathrm{P}-\mathrm{Rh}}$ coupling constants of 165.0 and $173.1 \mathrm{~Hz}$, and a $J_{\mathrm{P}-\mathrm{P}}$ of $51.3 \mathrm{~Hz}$ (Figure 4). On the other hand, the ${ }^{1} \mathrm{H}$ NMR spectrum evidenced the presence of the piperidonium cation $\left[\mathrm{H}_{2} \mathrm{NC}_{5} \mathrm{H}_{10}\right]^{+}$which shows a broad signal at $\delta 4.38$ for the $\mathrm{NH}_{2}$ group, and two resonances at $\delta 2.85$ and $1.57 \mathrm{ppm}$ for the methylene protons. ${ }^{19}$ The simultaneous formation of 9 and $\left[\mathrm{H}_{2} \mathrm{NC}_{5} \mathrm{H}_{10}\right]^{+}$strongly supports the formulation of $\mathbf{9}$ as an amido rhodium(I) complex whose structure, supported by DFT calculations, is shown in Scheme 2. Unfortunately, we were unable to observe the amido ligand by ${ }^{15} \mathrm{~N}$ NMR, however, it has been possible to identify the protons and carbons of the amido ligand, all of them inequivalent, through ${ }^{1} \mathrm{H},{ }^{1} \mathrm{H}-\mathrm{COSY}$ and ${ }^{1} \mathrm{H},{ }^{13} \mathrm{C}-\mathrm{HSQC}$ correlation experiments (Supporting information). In sharp contrast, when a solution of complex $\left[\mathrm{Rh}\left\{\mathrm{Ph}_{2} \mathrm{P}\left(\mathrm{CH}_{2}\right)_{3} \mathrm{OEt}\right\}_{2}\left(\mathrm{HNC}_{5} \mathrm{H}_{10}\right)\right]^{+}(7)$ in THF- $d_{8}$ was heated for $20 \mathrm{~h}$ the formation of 9 was never observed. This result supports the active role of piperidine in the formation of this key rhodium-amido species from $\mathbf{8}$. 


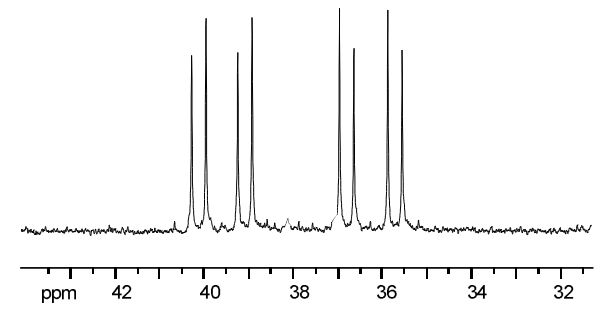

Figure 4. ${ }^{31} \mathrm{P}\left\{{ }^{1} \mathrm{H}\right\}$ NMR (THF- $\left.d_{8}, 298 \mathrm{~K}\right)$ of 9.

Most probably, 9 results from the deprotonation of one of the coordinated piperidine ligands in $\mathbf{8}$ by the second piperidine ligand (intramolecular) or, alternatively, by an external piperidine molecule (intermolecular). The elimination of $\left[\mathrm{H}_{2} \mathrm{NC}_{5} \mathrm{H}_{10}\right]^{+}$ produces a coordination vacant site which could be occupied, in principle, by a ethoxy group of one of the hemilabile ligands, a solvent molecule (thf) or piperidine. The possible dimerization of this unsaturated species can be ruled out because a symmetrical amido-bridged dinuclear should be formed which is not compatible with the observed spectroscopic data. ${ }^{10 b, 20}$ DFT calculations have shown that the amido species $\left[\mathrm{Rh}\left\{\mathrm{Ph}_{2} \mathrm{P}\left(\mathrm{CH}_{2}\right)_{3} \mathrm{OEt}\right\}_{2}\left(\mathrm{NC}_{5} \mathrm{H}_{10}\right)(\right.$ thf $\left.)\right]$ (9b) and $\left[\mathrm{Rh}\left\{\mathrm{Ph}_{2} \mathrm{P}\left(\mathrm{CH}_{2}\right)_{3} \mathrm{OEt}\right\}_{2}\left(\mathrm{NC}_{5} \mathrm{H}_{10}\right)\left(\mathrm{HNC}_{5} \mathrm{H}_{10}\right)\right]$ (9c-exo $)$ are -12.0 and -7.3 Kcal $\mathrm{mol}^{-1}$ more stable than $\left[\mathrm{Rh}\left\{\mathrm{Ph}_{2} \mathrm{P}\left(\mathrm{CH}_{2}\right)_{3} \mathrm{OEt}\right\}_{2}\left(\mathrm{NC}_{5} \mathrm{H}_{10}\right)\right](\mathbf{9 a})$ having one of the hemilabile phosphine ligands $\kappa^{2}-\mathrm{P}, \mathrm{O}$ coordinated (Figure 5). However, the optimization of the structure of 9 with the $\mathrm{NH}$ proton with a relative endo disposition to the amido ligand (9c-endo), resulted in a net stabilization of $-12.11 \mathrm{Kcal} \mathrm{mol}^{-1}$ relative to $9 \mathrm{a}$. In this optimized structure, the hydrogen bond between the $\mathrm{NH}$ of the coordinated piperidine and the nitrogen atom of the amido ligand in $\left(\mathrm{NH}^{\cdots \cdots} \mathrm{N}\right.$ distance of $1.856 \AA$ ) produces a narrow $\mathrm{N}-\mathrm{Rh}-\mathrm{N}$ angle of $73.91^{\circ}$ (Figure 6). This interaction probably blocks the two coordination sites thereby preventing the piperidine exchange and, in contrast with compound $\mathbf{8 , 9}$ is static.

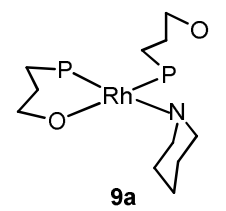<smiles>CCCN[Pb](N1CCCCC1)(P(CCO)CCO)P(CCO)CCO</smiles>

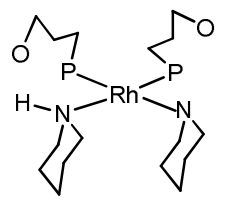

9c-exo

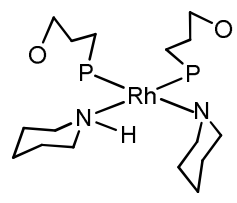

9c-endo

Figure 5. Possible structures for he neutral amido species $\mathbf{9 .}$

Thus, DFT calculations allow us to formulate $\mathbf{9}$ as a neutral amido-piperidine square-planar rhodium(I) complex $\left[\mathrm{Rh}\left\{\mathrm{Ph}_{2} \mathrm{P}\left(\mathrm{CH}_{2}\right)_{3} \mathrm{OEt}\right\}_{2}\left(\mathrm{NC}_{5} \mathrm{H}_{10}\right)\left(\mathrm{HNC}_{5} \mathrm{H}_{10}\right)\right]$ stabilized by a $\mathrm{NH}^{\cdots \cdots} \mathrm{N}$ hydrogen bond (Scheme 2).

The reactivity of the cyclooctadiene complexes $\left[\mathrm{Rh}(\operatorname{cod})\left\{\square \kappa^{2}-\right.\right.$ $\left.\left.\mathrm{P}, \mathrm{O}-\mathrm{Ph}_{2} \mathrm{P}\left(\mathrm{CH}_{2}\right)_{3} \mathrm{OEt}\right\}\right]^{+}(\mathbf{1})$ and $\left[\mathrm{Rh}(\mathrm{cod})\left\{\kappa^{1}-\mathrm{P}-\mathrm{Ph}_{2} \mathrm{P}\left(\mathrm{CH}_{2}\right)_{3} \mathrm{OEt}\right\}_{2}\right]^{+}$ (3) with piperidine was also monitored by NMR. The addition of

one equivalent of piperidine to a suspension of complex $\left[\mathrm{Rh}(\mathrm{cod})\left\{\mathrm{Ph}_{2} \mathrm{P}\left(\mathrm{CH}_{2}\right)_{3} \mathrm{OEt}\right\}\right]^{+}(\mathbf{1})$ in THF- $d_{8}$ gave an equimolecular mixture of complexes $\left[\mathrm{Rh}(\mathrm{cod})\left\{\mathrm{Ph}_{2} \mathrm{P}\left(\mathrm{CH}_{2}\right)_{3} \mathrm{OEt}\right\}_{2}\right]^{+}$(3) and $\left[\mathrm{Rh}(\operatorname{cod})\left(\mathrm{HNC}_{5} \mathrm{H}_{10}\right)_{2}\right]^{+}(\mathbf{1 0})$ as a result of a ligand redistribution reaction (Scheme 3). Compound $\mathbf{1 0}$ has been identified in the ${ }^{1} \mathrm{H}$ NMR spectrum by comparison with a sample independently prepared by reaction of $\left[\mathrm{Rh}(\operatorname{cod})_{2}\right]^{+}$with two equivalents of piperidine in $\mathrm{THF}-d_{8}$.

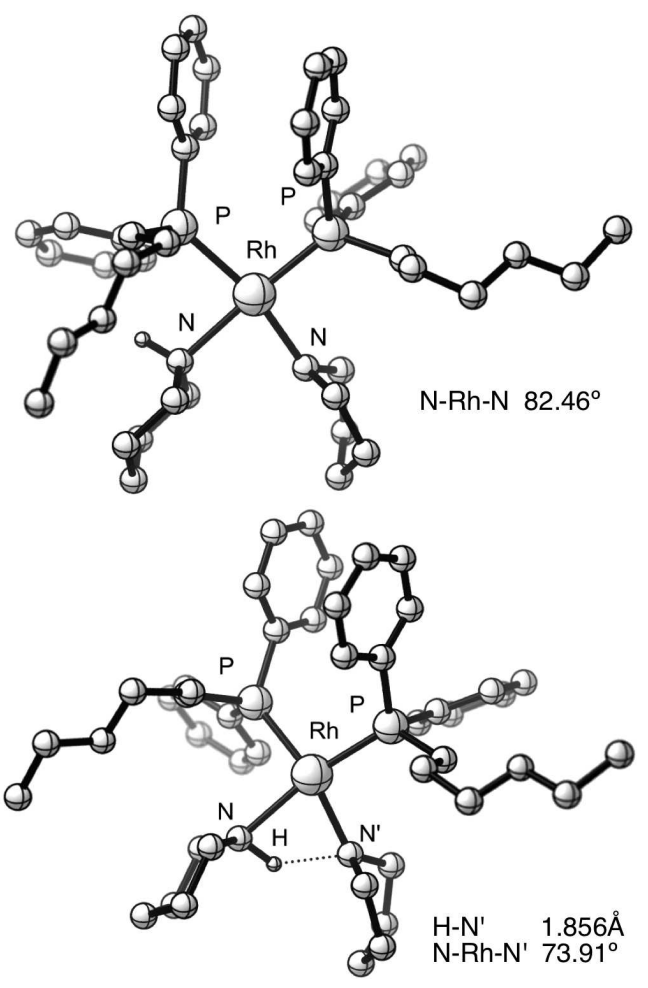

Figure 6. DFT geometry-optimized structure of $\mathbf{9 c - e x o}$ (top) and 9c-endo (bottom).
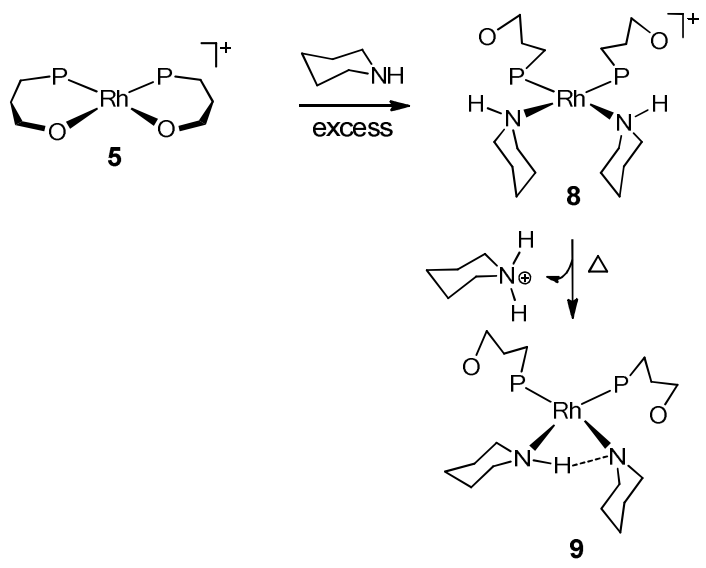

Scheme 2. Formation of the amido-piperidine rhodium(I) 9 from 5. 

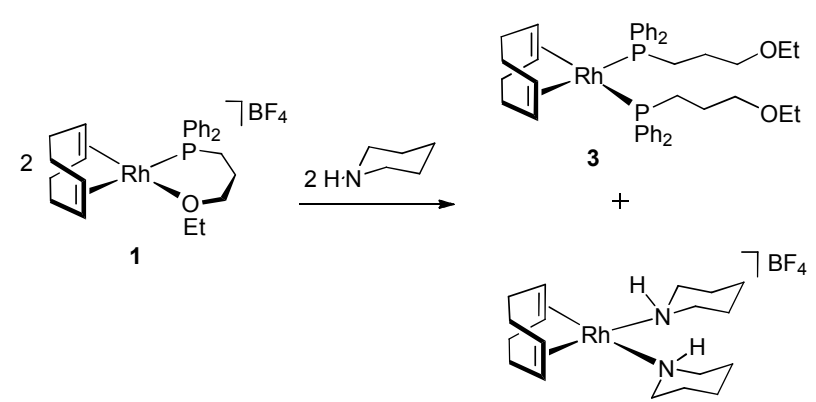

10

Scheme 3. Ligand redistribution reaction involving $\mathbf{1}$ and piperidine.

Addition of 40 equiv. of piperidine to a suspension of complex $\left[\mathrm{Rh}(\mathrm{cod})\left\{\mathrm{Ph}_{2} \mathrm{P}\left(\mathrm{CH}_{2}\right)_{3} \mathrm{OEt}\right\}_{2}\right]^{+}(3)$ in THF- $d_{8}$ and heating for ca. 20 min. at $333 \mathrm{~K}$, or $24 \mathrm{~h}$ at room temperature, gave a dark red solution containing a new compound 11. The ${ }^{31} \mathrm{P}\left\{{ }^{1} \mathrm{H}\right\}$ NMR spectrum showed a doublet at $\delta 30.80 \mathrm{ppm}\left(J_{\mathrm{P}-\mathrm{Rh}}=200.2 \mathrm{~Hz}\right)$ and the ${ }^{1} \mathrm{H}$ NMR spectrum evidenced the presence of coordinated cyclooctadiene. Interestingly, compound $\mathbf{1 1}$ has also been observed in the reaction of $\left[\mathrm{Rh}(\mathrm{cod})\left\{\mathrm{Ph}_{2} \mathrm{P}\left(\mathrm{CH}_{2}\right)_{3} \mathrm{OEt}\right\}_{2}\right]^{+}(3)$ with $\mathrm{LiNC}_{5} \mathrm{H}_{10}$ in THF- $d_{8}$ or $\mathrm{C}_{6} \mathrm{D}_{6}$. Thus, this compound has been tentatively identified as the neutral amido complex $\left[\mathrm{Rh}(\mathrm{cod})\left\{\mathrm{Ph}_{2} \mathrm{P}\left(\mathrm{CH}_{2}\right)_{3} \mathrm{OEt}\right\}_{2}\left(\mathrm{NC}_{5} \mathrm{H}_{10}\right)\right]$ (11). The spectroscopic data for 11 suggest a symmetrical structure with equivalent phosphine ligands and are compatible with a square pyramidal structure having the amido ligand in the apical position. More importantly, when a solution of $\mathbf{1 1}$, prepared by reaction of $\mathbf{3}$ with an excess of piperidine, was heated at $333 \mathrm{~K}$ for 4 hours the only species observed in the ${ }^{31} \mathrm{P}\left\{{ }^{1} \mathrm{H}\right\}$ NMR was the amido complex 9 (Scheme 4). The transformation of $\mathbf{1 1}$ into $\mathbf{9}$ requires the elimination of cyclooctadiene. In this context, it is worth nothing that the investigation of the some of the catalytic solutions by GC/MS allowed the detection of a peak with a $\mathrm{m} / \mathrm{z}$ ratio of 191 corresponding to 1-(cycloocta-1,5-dien-1-yl)piperidine. ${ }^{14}$ Thus, the oxidative amination of the coordinated 1,5-cyclooctadiene ligand is necessary for the generation of active catalytic species when using complexes $\mathbf{1}$ and $\mathbf{3}$ as catalyst precursors.

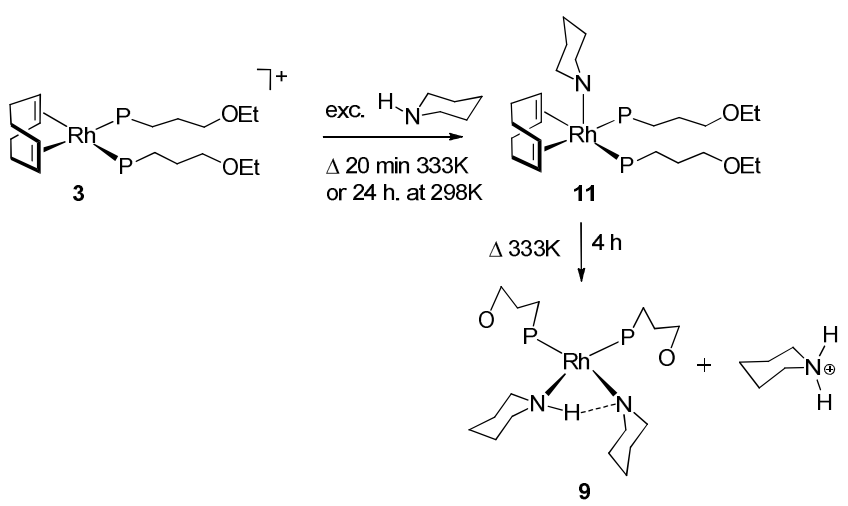

Scheme 4. Formation of the amido-piperidine rhodium(I) 9 from 3

\section{The catalytic active species at work.}

The precedent reactivity studies have shown that the three different types of catalyst precursors react with piperidine under thermal conditions to give the same species. Spectroscopic data and DFT calculations allow us to propose the neutral amido- piperidine complex $\left[\mathrm{Rh}\left\{\mathrm{Ph}_{2} \mathrm{P}\left(\mathrm{CH}_{2}\right)_{3} \mathrm{OEt}\right\}_{2}\left(\mathrm{NC}_{5} \mathrm{H}_{10}\right)\left(\mathrm{HNC}_{5} \mathrm{H}_{10}\right)\right]$ (9) as a key species in the oxidative amination of styrene with piperidine. In order to confirm this hypothesis, further NMR studies carried out in the presence of styrene under catalytic conditions have been carried out.

Thus, styrene and piperidine were added to a solution of $\mathbf{5}$ in THF- $d_{8}$, molar ratio $160: 40: 1$, heated in a thermostathized bath at $338 \mathrm{~K}$ and then monitored by ${ }^{1} \mathrm{H} \mathrm{NMR}$ at the same temperature (Figure 7). Under these catalytic conditions, the formation of $(E)$ 1 -styrylpiperidine and ethylbenzene was detected after $20 \mathrm{~min}$. The two resonances at $\delta 6.49$ and $5.26 \mathrm{ppm}$ correspond to the $\mathrm{C}=\mathrm{H}$ protons of $(E)$-1-styrylpiperidine. The ethylbenzene was identified by the characteristic triplet and quartet resonances at $\delta 1.21$ and $2.58 \mathrm{ppm}$ of the ethyl substituent. As expected, an increase of the intensity of these resonances with the concomitant decrease of those corresponding to styrene was observed with the progress of the reaction.

In a parallel experiment, a THF- $d_{8}$ solution containing catalyst 5, piperidine and styrene and in a $1: 40: 160$ molar ratio was heated in a thermostathized bath at $338 \mathrm{~K}$ and monitored regularly by ${ }^{31} \mathrm{P}\left\{{ }^{1} \mathrm{H}\right\}$ NMR spectra at $273 \mathrm{~K}$. After $20 \mathrm{~min}$, a mixture of the cationic piperidine complex $\mathbf{8}$ and the neutral species 9 was observed. Interestingly, 9 was the only species detected after heating at $338 \mathrm{~K}$ for one hour (Figure 8).

The above described results suggest that the piperidine-amido complex 9 could be competent for the catalytic hydroamination of styrene. The formation of $\mathbf{9}$ from the catalyst precursor $\mathbf{5}$ requires the amine activation through the piperidine intermediate species $\mathbf{8}$. However, in order to rule out the possible involvement of the olefin in the generation of an active species, we have studied the reactivity of 5 with styrene. The addition of a large excess of styrene to a dissolution of 5 in THF- $d_{8}(160: 1)$ resulted in the formation of a symmetric species $\mathbf{1 2}$ which was observed at $\delta$ $33.93 \mathrm{ppm}\left(J_{\mathrm{P}-\mathrm{Rh}}=204.1 \mathrm{~Hz}\right)$ in the ${ }^{31} \mathrm{P}\left\{{ }^{1} \mathrm{H}\right\}$ NMR spectrum at 273 $\mathrm{K}$. The spectroscopic data for $\mathbf{1 2}$ suggest the formation of an olefin adduct $\left.\left[\mathrm{Rh}\left\{\mathrm{Ph}_{2} \mathrm{P}\left(\mathrm{CH}_{2}\right)_{3} \mathrm{OEt}\right\}_{2} \text { (styrene }\right)_{n}\right]^{+}$. It is worth of note that this species has never been observed by ${ }^{31} \mathrm{P}\left\{{ }^{1} \mathrm{H}\right\}$ NMR under catalytic conditions. In agreement with this, the addition of 40 equiv. of piperidine resulted in the formation of $\mathbf{8}$ by replacement of the coordinated styrene, and more importantly, in the steady formation of the amido-piperidine $\mathbf{9}$ even at room temperature. 


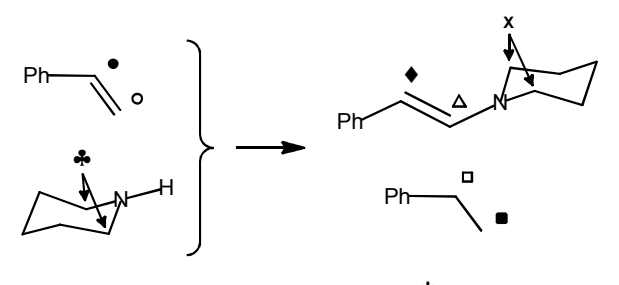

$*=$ tetradecane

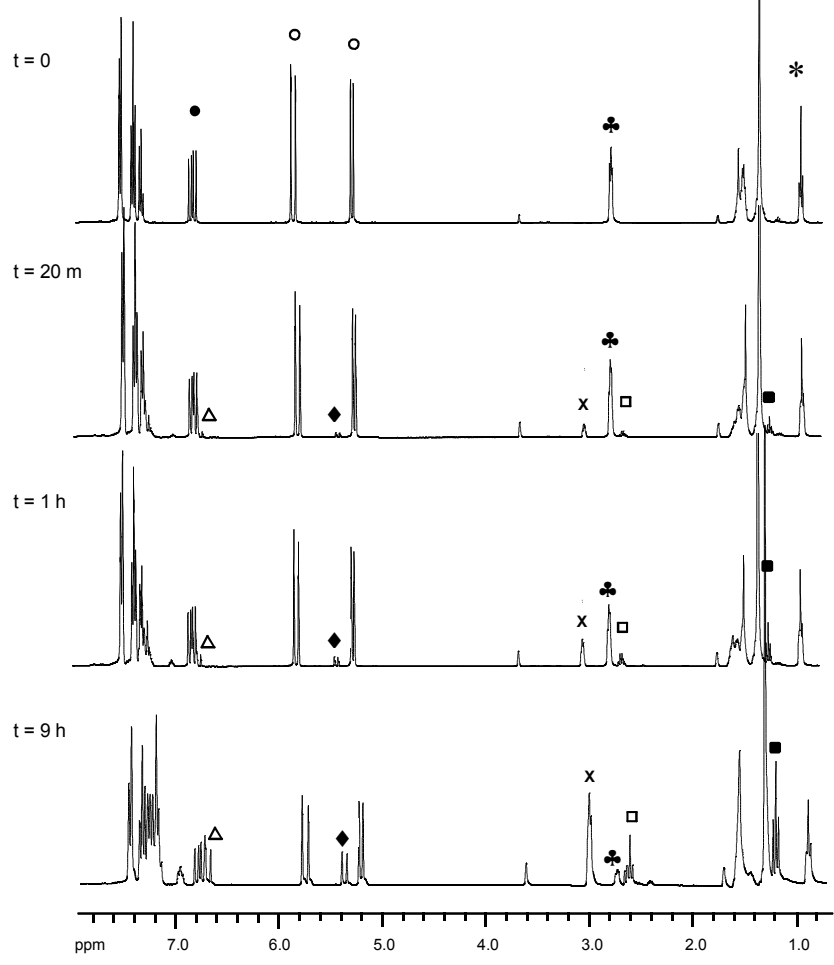

Figure 7. ${ }^{1} \mathrm{H}$ NMR spectra at $338 \mathrm{~K}$ of the oxidative amination of styrene with piperidine catalysed by complex $\mathbf{5}$ at different reaction times. Styrene/piperidine/catalyst: $160 / 40 / 1 ;[\mathrm{Rh}]=0.01 \mathrm{M}$ in $0.5 \mathrm{~mL} \mathrm{THF}-d_{8}$.

8
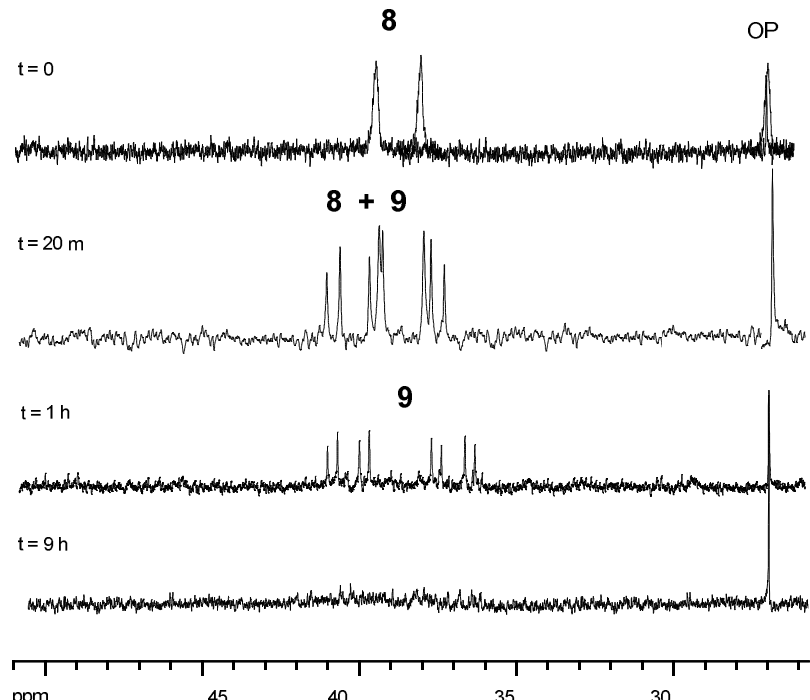

ure $8 .{ }^{31} \mathrm{P}\left\{{ }^{1} \mathrm{H}\right\}$ NMR at $273 \mathrm{~K}$ spectra of the oxidative amination of styrene with piperidine catalysed by complex $\mathbf{5}$ at different reaction times. Styrene/piperidine/catalyst: $160 / 40 / 1 ;[\mathrm{Rh}]=0.01 \mathrm{M}$ in $0.5 \mathrm{~mL}$ THF- $d_{8}$. Conversion to enamine: $\mathrm{t}=20 \mathrm{~min}, 13 \% ; \mathrm{t}=1 \mathrm{~h}, 35 \% ; \mathrm{t}=9 \mathrm{~h}, 98 \%$. $\mathrm{OP}=$ phosphine oxide.
The spectroscopic information obtained from the reactivity studies confirms that the mechanism of oxidative amination of styrene proceeds through the activation of the amine, regardless the catalyst precursor, and involve the same key catalytic species, most probably, the neutral amido-piperidine $\left[\mathrm{Rh}\left\{\mathrm{Ph}_{2} \mathrm{P}\left(\mathrm{CH}_{2}\right)_{3} \mathrm{OEt}\right\}_{2}\right.$ $\left.\left(\mathrm{NC}_{5} \mathrm{H}_{10}\right)\left(\mathrm{HNC}_{5} \mathrm{H}_{10}\right)\right](9)$. Consequently, the catalytic activity of the different catalyst precursors must be related to the concentration of this species. This interpretation is supported by the similar regioselectivity, around $96 \%$ in $(E)$-1-styrylpiperidine, observed for the three types of catalytic precursors (Table 1).

\section{Mechanism of the catalytic oxidative amination.}

The regioselective intermolecular anti-Markovnikov hydroamination and oxidative amination of aromatic olefins with secondary amines catalysed by the system $\left[\mathrm{Rh}(\operatorname{cod})_{2}\right] \mathrm{BF}_{4} / 2 \mathrm{PPh}_{3}$ was studied by Beller's group. ${ }^{21}$ The reaction proceeds through independent catalytic amination cycles and kinetic investigations have shown that in both cases the reaction rates are dependent both on the styrene and the catalyst concentrations, and independent of the amine concentration. Mechanistic studies allowed concluding that rhodium hydride complexes were participating in the catalytic cycle. The proposed mechanism, which is shown in figure 9, follows an amine activation pathway where the key hydrido-amido intermediate is formed by oxidative addition of the amine.

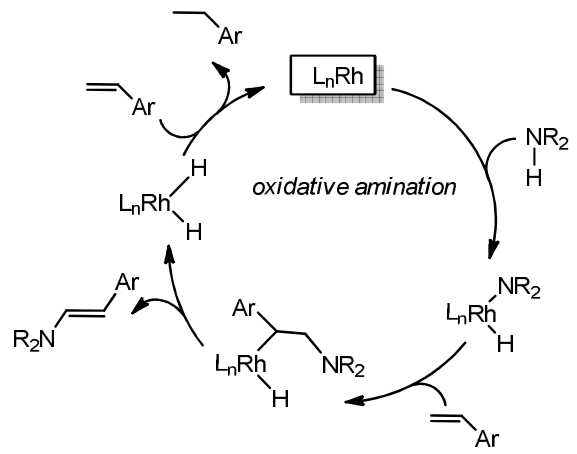

Figure 9. Mechanism proposed by Beller for the oxidative amination of aromatic olefins with secondary amines.

The formation of the amido complex $\mathbf{9}$ from $\left[\mathrm{Rh}\left\{\mathrm{Ph}_{2} \mathrm{P}\left(\mathrm{CH}_{2}\right)_{3} \mathrm{OEt}\right\}_{2}\left(\mathrm{HNC}_{5} \mathrm{H}_{10}\right)_{2}\right]^{+}(\mathbf{8})$ in the presence of piperidine (Scheme 2) probably takes place through the intermolecular deprotonation of a coordinated piperidine ligand. An alternative pathway for the formation of 9 could be the oxidative addition of piperidine followed by deprotonation of the resulting hydride complex, however we failed to observe by ${ }^{1} \mathrm{H}$ NMR any hydride intermediate in the formation of 9 both under stoichiometric and catalytic conditions. On the other hand, the intermolecular transfer of amido ligands from rhodium(I) amides to unactivated olefins have been recently reported. ${ }^{22,23}$ On the basis of these results, we propose that the oxidative amination catalysed by rhodium complexes containing $\mathrm{P}, \mathrm{O}$-functionalized phosphine ligands proceeds through the catalytic cycle shown in figure 10 . 
<smiles>C=CN[Pb](NC=C)P(CO)OCC</smiles><smiles>CC(C)(C)C(C)(C)C1CCNC1</smiles>

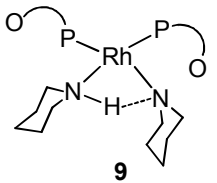<smiles>CC(C)=Cc1ccccc1</smiles>

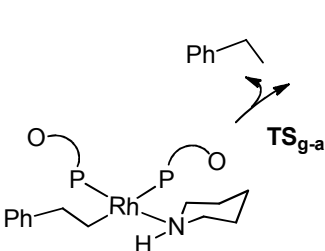

(g)

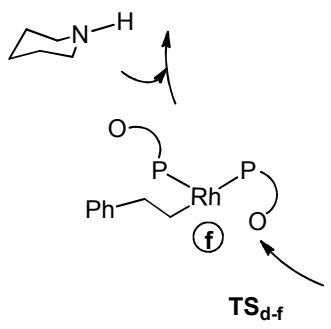
$\mathrm{TS}_{\mathrm{d}-\boldsymbol{f}}$

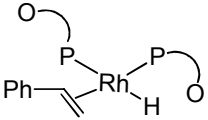

(d)<smiles>C=CN[PbH](CO)PC=C</smiles>

Figure 10. Proposed mechanism for the oxidative amination of styrene with piperidine catalysed by rhodium complexes containing $\mathrm{P}, \mathrm{O}$-functionalized phosphine ligands.

The first step of the proposed mechanism is the replacement of the piperidine ligand by styrene in $\mathbf{9}$ to give a key styrene-amido intermediate. Then, the insertion of styrene into the rhodium-amide bond should results in the formation of an alkylamine intermediate, giving the enamine product by a $\beta$-elimination process. Finally, the regeneration of the catalytic active species requires the hydrogenation of a second styrene molecule as it is discussed below.

The influence of the styrene concentration on the activity and selectivity was also investigated (Table 2). Under the standard catalytic conditions a molar ratio catalyst/amine/olefin of 1/40/160 was used (olefin/amine ratio of 4). In general, the catalytic activity increased with increasing the olefin concentration. For example, for catalyst 5 an increase of the olefin/amine ratio to 8 resulted in an upsurge of the conversion from $66 \%$ to $94 \%$ in only half hour (entry 2, Table 2). The positive influence of the olefin concentration on the catalytic activity can be rationalized by the shift of the equilibria involving the amino-amido species 9 towards the olefin-amido intermediate a (Figure 10), or from e towards d intermediates. In addition, this positive effect is also in agreement with the hydrogen acceptor role of the olefin in the generally accepted oxidative amination mechanism, ${ }^{1,24}$ and related borylation and silylation processes. ${ }^{25}$

Table 2. Oxidative amination of styrene with piperidine catalysed by rhodium bisphosphine complexes at different olefine/amine ratios. ${ }^{\text {a }}$

\begin{tabular}{|c|c|c|c|c|c|c|c|c|}
\hline \multicolumn{4}{|c|}{ styrene/piperidine $\rightarrow$} & \multicolumn{2}{|l|}{2} & \multicolumn{2}{|c|}{4} & 3 \\
\hline & Cat. & $\mathrm{t} / \mathrm{h}$ & Conv. ${ }^{b}$ & Selec. ${ }^{c}$ & Conv. ${ }^{b}$ & Selec. $^{c}$ & Conv. ${ }^{b}$ & Selec. ${ }^{\mathrm{c}}$ \\
\hline 1 & 3 & 4 & 50 & $94 / 6$ & 92 & $96 / 4$ & 100 & $96 / 4$ \\
\hline 2 & 5 & 0.5 & 42 & $93 / 7$ & 66 & $95 / 5$ & 94 & $95 / 5$ \\
\hline 3 & 6 & 0.5 & 46 & $93 / 7$ & 75 & $96 / 4$ & 96 & $95 / 5$ \\
\hline
\end{tabular}

[a] Reaction conditions: piperidine/cat: $40 / 1,[\mathrm{Rh}]=0.01 \mathrm{M}$ in $2.5 \mathrm{~mL}$ THF, $80{ }^{\circ} \mathrm{C}$. [b] Standard conditions of analysis. Conversion relative to the piperidine (\%) determined by $\mathrm{GC}$ analysis using tetradadecane as internal standard. [c] Selectivity: (E)-1styrylpiperidine/1-phenethylpiperidine ratio.

On the other hand, the observed selectivity is practically the same for olefine/amine ratios higher than 4 and only a slightly decrease of selectivity was observed with an olefin/amine ratio of 2 . These results are parallel to those obtained by Beller ${ }^{21,26}$ and contrast with the observed by Hartwig et al for the antiMarkovnikov hydroamination of vinylarenes with secondary amines using a rhodium complex of DPEphos. ${ }^{27}$ The higher enamine:amine ratios at higher concentrations of vinylarene was interpreted by the participation of two vinylarenes in the transition state that controls the selectivity in a hydrido-rhodium intermediate.

\section{DFT calculations on the mechanism of the catalytic oxidative amination.}

As it is apparent from the proposed catalytic cycle, the hemilabile ligand can play an important role in the mechanism because of its potential for the reversible protection of one or more coordination sites by an alternating "on/off" mechanism. In order to understand the outstanding catalytic activity of the complexes having hemilabile $\mathrm{P}, \mathrm{O}$-functionalized phosphine ligands we have studied the key steps of the proposed mechanism by DFT calculations.

The catalytic cycle has been studied by a series of DFT calculations on the successive steps (Figure 10) using the B3LYP functional as implemented in Gaussian $09,{ }^{28}$ and with a Lanl2dz basis and ECP for rhodium and 6-31G** basis for the rest of elements. The transition states of the key steps have been found and characterized. The energy profile for the catalytic cycle is shown in Figure 11. The energies reported are gas-phase values with ZPE corrections. The substitution processes have been assumed to require low activation energy values. ${ }^{29,30,31}$

The neutral square planar rhodium(I) amino-amido complex 9 is the precursor for the catalytic active species: the olefin-amido intermediate $\left[\mathrm{Rh}\left\{\mathrm{Ph}_{2} \mathrm{P}\left(\mathrm{CH}_{2}\right)_{3} \mathrm{OEt}\right\}_{2}\left(\mathrm{NC}_{5} \mathrm{H}_{10}\right)\right.$ (styrene)] (a, Figure 10). The resulting complex a presents a distorted square planar geometry where the amido $\mathrm{N}$-atom forms an angle of $95.08^{\circ}$ with the C-C centroid of the olefin group which lies roughly perpendicular to the coordination plane. DFT calculations show that the styrene complex is less stable than the piperidine complex 
9 by $+7.64 \mathrm{kcal} / \mathrm{mol}$, and consequently the replacement of the piperidine ligand in 9 by styrene is an endothermic process.
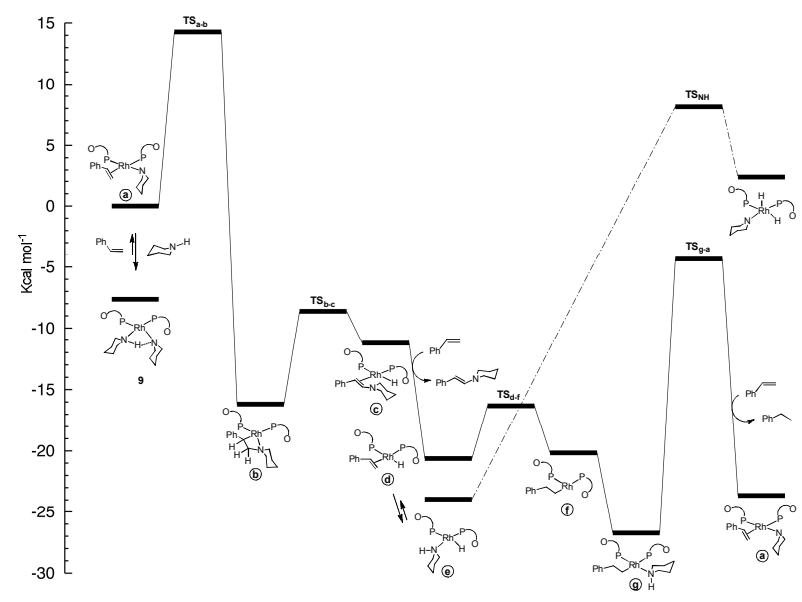

Figure 11. Calculated energy profile for catalytic cycle for the catalytic oxidative amination of styrene.

The styrene coordination is followed by the insertion into the Rh-amido bond to produce an aminoalkyl intermediate $\mathbf{b}$ (Figure 10). The formation of a metallacyclic $\alpha$-amino, $\beta$-arylalkyl stabilizes the system by $-16.17 \mathrm{kcal} / \mathrm{mol}$. The process requires an activation energy of $\Delta \mathrm{E}=+14.27 \mathrm{kcal} / \mathrm{mol}$ through the transition state $\mathbf{T S}_{\mathbf{a}-\mathbf{b}}$ (Figure 11) which has been confirmed by frequency calculations. In the transition state the $\mathrm{C}-\mathrm{N}$ distance has reduced from the initial value of $3.027 \AA$ (N-Rh-C angle of $88.77^{\circ}$ ) to 2.188 $\AA$ (N-Rh-C angle of $54.14^{\circ}$ ) (Figure 12 a). Inspection of the imaginary mode shows the connection to the starting and final species of the process. The structural features of the metallacyclic amino-alkyl insertion product deserve further comments. The insertion process affords a coordinatively unsaturated species that could be stabilized by coodination of a pending ethoxy group on a hemilabile phosphine ligand. However, the weak coordination ability of this group is pointed out by the fact that optimization in vacuo starting from a chelating ether-phosphine ligand leads to a $\eta^{3}$-benzyl coordination of the aminoalkyl ligand. Nevertheless, this species is less stable than $\mathbf{b}$ with the aminoalkyl ligand $\kappa^{2}-\mathrm{C}, \mathrm{N}$ coordinated. The two protons of the methylene group in the four membered metallacycle have equatorial and axial dispositions, respectively. The rhodium-axial proton distance, the shortest one, was driven to shorter values searching for a transition state towards the elimination process leading to the (E)-1-styrylpiperidine reaction product.

The formation of the $\pi$-styrylpiperidine complex $\mathbf{c}$ by $\beta$-hydride elimination requires $+4.94 \mathrm{kcal} / \mathrm{mol}$ through a transition state, $\mathbf{T S}_{\mathbf{b}}$ , with an activation energy of $+7,55 \mathrm{kcal} / \mathrm{mol}$ (Figure 11). The hydrogen distances in $\mathbf{T S}_{\mathbf{b} \text {-c }}$ are $1.623 \AA$ to the carbon atom and $1.625 \AA$ to the Rh centre (Figure $12 \mathrm{~b}$ ). The rhodium coordination environment is almost planar with both $\mathrm{P}$ and $\mathrm{C}$ atoms and the eliminated hydrogen atom in roughly the same plane. On the other hand, the coordinated styrylpiperidine ligand in intermediate $\mathbf{c}$ can be replaced by any of the following ligands: a molecule of styrene, a molecule of piperidine or the ethoxy group of the free arm of the phosphine. Whereas the last process is slightly endothermic $(+4.93$ $\mathrm{kcal} / \mathrm{mol})$, the replacement of the olefin by styrene to give $\mathbf{d}(-9.39$ $\mathrm{kcal} / \mathrm{mol})$ or by piperidine to give e $(-12.72 \mathrm{kcal} / \mathrm{mol})$ are exothermic and close in energy which suggest that both species could be in equilibrium (Figure 11).
The catalytic reaction yields equimolar amounts of aminated and hydrogenated styrene products, which suggests that the hydrogenation is concomitant with the amination process. From here on, two paths leading to styrene hydrogenation could be devised. In one way, the coordination and oxidative addition of piperidine in e would generate an amido-dihydrido complex that could react with styrene leading to hydrogenation. In this pathway the resulting dihydrido complex is $26.3 \mathrm{kcal} / \mathrm{mol}$ above the hydrido-piperidine reactant and the $\mathrm{N}-\mathrm{H}$ oxidative addition process requires an activation energy of $32.09 \mathrm{kcal} / \mathrm{mol}$ through the $\mathbf{T} \mathbf{S}_{\mathbf{N H}}$ transition state (dashed line pathway, Figure 11).

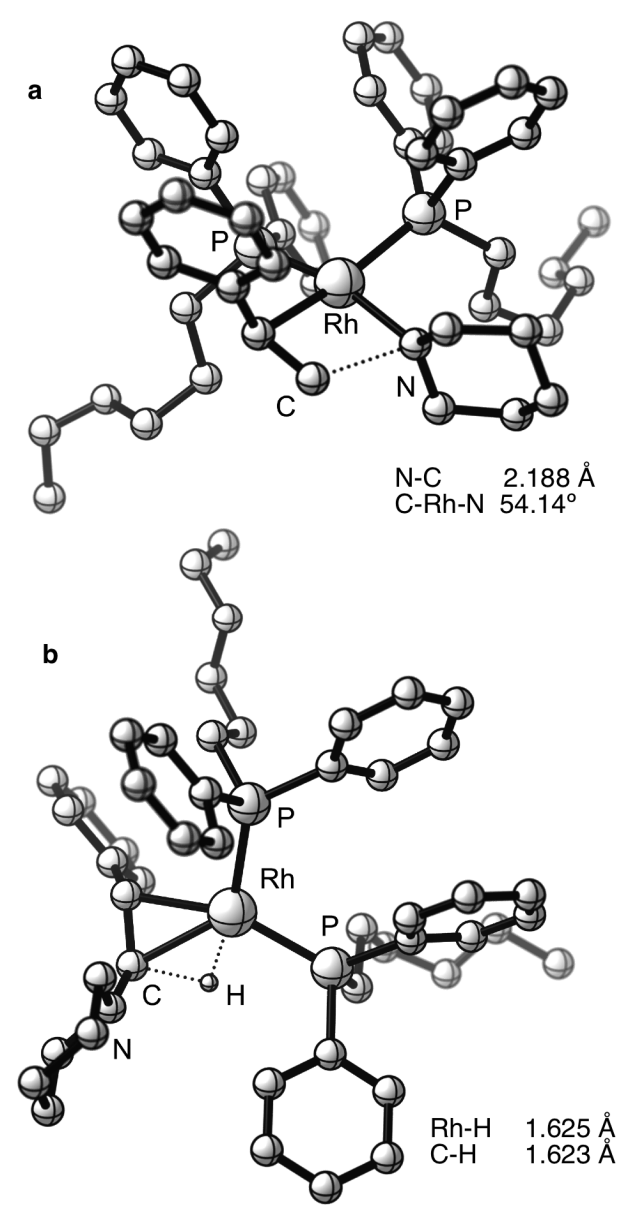

Figure 12. Structures for transition states $\mathbf{T} \mathbf{S}_{\mathbf{a}-\mathbf{b}}$ (a) and $\mathbf{T} \mathbf{S}_{\mathbf{b}-\mathbf{c}}$ (b).

The second pathway, which is the less energetically demanding, occurs via substitution of $\pi$-styrylpiperidine in complex $\mathbf{c}$ by styrene (solid line pathway, Figure 11). This complex can generate an alkyl intermediate $\mathbf{f}$ by a facile olefin insertion into the Rh-H bond which is slightly endothermic by only $0.5 \mathrm{kcal} / \mathrm{mol}$, and requires only $4.32 \mathrm{kcal} / \mathrm{mol}$ of activation energy $\left(\mathbf{T S}_{\mathbf{d}-\mathbf{f}}\right.$, Figure 13 a). Coordination of piperidine in the resulting vacant coordination site stabilizes the product by $-6.56 \mathrm{kcal} / \mathrm{mol}$ (g, Figure 11). From this point, a direct transfer of the amine proton from the piperidine ligand to the alkyl group requires just an activation energy of 22.38 $\mathrm{kcal} / \mathrm{mol}\left(\mathbf{T S}_{\mathrm{g}-\mathrm{a}}\right.$, Figure $\left.13 \mathrm{~b}\right)$ to give the hydrogenated product ethylbenzene $(+7.55 \mathrm{kcal} / \mathrm{mol})$ completing the catalytic cycle. The difference in energy between both alternatives suggests that this second pathway is the operating one in the catalytic cycle. 

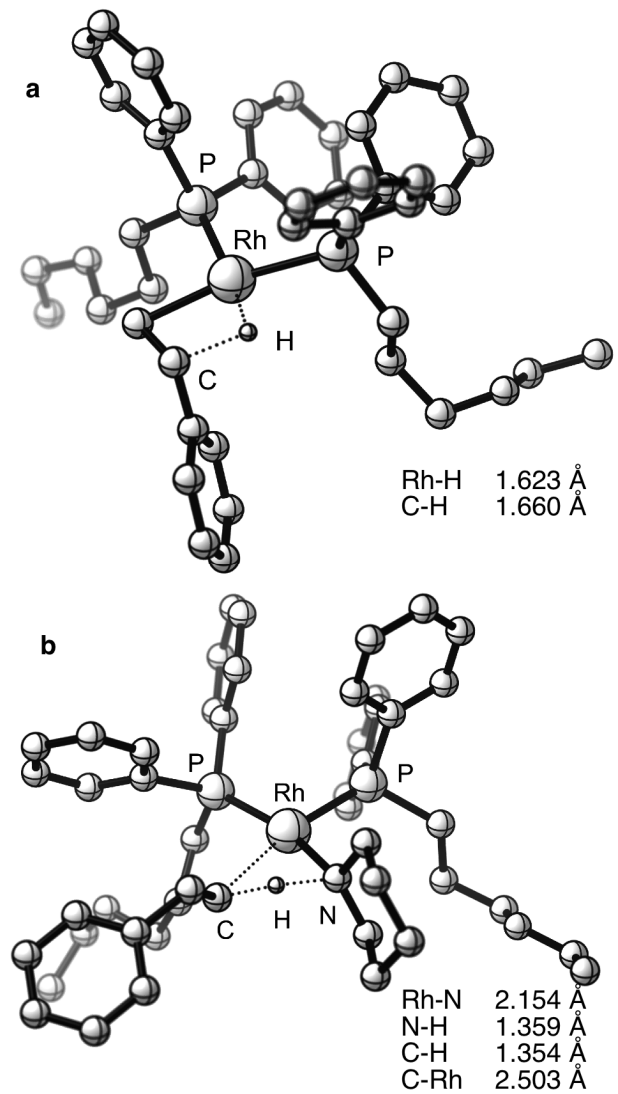

Figure 13. Structures for transition states $\mathbf{T S} \mathbf{S}_{\mathbf{e - f}}$ (a) and $\mathbf{T} \mathbf{S}_{\mathrm{g}-\mathrm{a}}$ (b).

The above described results suggest that the formation of the amine product, 1-phenethylpiperidine (Table 1), could take place from the metallacyclic aminoalkyl intermediate $\mathbf{b}$, through the coordination of piperidine and proton transfer of the piperidine proton to the amino alkyl ligand resulting in the regeneration of the active catalyst species a. On the other hand, the oxidative addition of piperidine to $\mathbf{b}$ seems to be unlikely on the light of the precedent results. Thus, the high selectivity for the enamine product is a consequence of the stability of the metallacyclic amino-alkyl intermediate $\mathbf{b}$ with a conformation that facilitates the B-hydride elimination to the $\pi$-styrylpiperidine intermediate $\mathbf{c}$.

The computational study on the full catalytic cycle for the oxidative amination of styrene with piperidine has failed to identify the role of the hemilabile fragment of the functionalized phosphine ligands. In fact, the 3-ethoxypropyl moieties of both phosphine ligands are far away from the rhodium centre in the optimized structures of the intermediates. In addition, these groups do not seem to have any influence in the transition states involved in the keys steps of the catalytic cycle.

However, the relative cis arrangement of the functionalized phosphine ligands in the intermediates along the catalytic cycle could play an important role. The determination of the molecular structure of complexes $\mathbf{5}$ and $\mathbf{6}$ allowed the identification of a $\pi-\boldsymbol{\pi}$ intramolecular interaction between two phenyl groups of the two phosphines. ${ }^{14,15}$ This interaction provides a rigid scaffold in the intermediates that directs both hemilabile arms of the phosphine ligands on the same side of the molecular plane towards the metal centre facilitating the coordination of both ethoxypropyl fragments and in turn, the protection of the two accessible coordination sites necessaries for the catalysis (Figure 14). Thus, the observed hemilabile effect could be related with the stabilization of polar species in solution, as the key intermediate $\left[\mathrm{Rh}\left\{\mathrm{Ph}_{2} \mathrm{P}\left(\mathrm{CH}_{2}\right)_{3} \mathrm{OEt}\right\}_{2}\left(\mathrm{NC}_{5} \mathrm{H}_{10}\right)\left(\mathrm{HNC}_{5} \mathrm{H}_{10}\right)\right]$ (9), or unsaturated catalytic intermediates by transient $\mathrm{O}$-coordination as for example, those resulting after the decoordination of the $\pi$-styrylpiperidine ligand in $\mathbf{c}$ or the styrene insertion in $\mathbf{d}$.

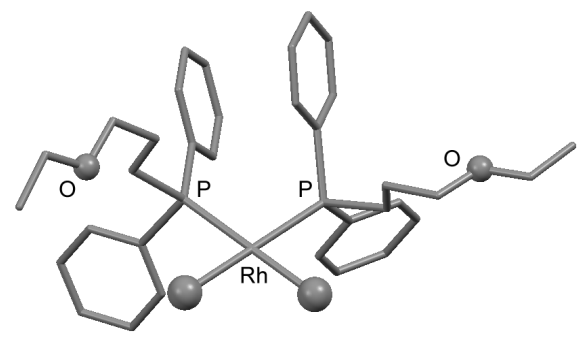

Figure 14. Cis arrangement of the O-functionalized phosphine ligands in an intermediate model showing a $\pi$ - $\pi$ intramolecular interaction.

Scope and limitations of the anti-Markonikov oxidative amination of aromatic olefines

The catalyst $\left[\mathrm{Rh}\left\{\mathrm{Ph}_{2} \mathrm{P}\left(\mathrm{CH}_{2}\right)_{3} \mathrm{OEt}\right\}_{2}\right]\left[\mathrm{PF}_{6}\right](5)$ has been applied for the oxidative amination of substituted vinylarenes with several amines (Table 3). The reactions either of electron-poor or electronrich vinylarenes with piperidine in presence of $2.5 \mathrm{~mol} \%$ of 5 gave the corresponding $(E)$ - 1-styrylpiperidine derivatives with excellent selectivity (entries 1-6). In general, the catalytic activity was negatively affected by the presence of a substituent in the styrene. In particular, ortho substituents largely influenced the catalytic activity although the steric influence was also observed for substrates with substituents in para position (entries 1-4). The introduction of electron density in the styrene aromatic ring in the para position resulted in a slight decrease in the catalytic activity, which is significantly higher for the more reactive electron poor styrenes (entry 5). These results suggest a complex interplay between the electronic and steric effects exerted by the substituent. In addition to the decrease of activity, the substitution on the vinylarene resulted in a moderate decrease of the enamine selectivity, typically from $96 \%$ to $90 \%$, especially at long reaction times.

Other secondary amines are also suitable for the oxidative amination of styrene (Table 3, entries 7-10). Morpholine, a cyclic amine less basic than piperidine (piperidine, $p K_{b}=2.88$; morpholine, $p K_{b}=5.67$ ) showed a comparable activity and complete selectivity to the enamine product. However, pyrrolidine with a similar basicity $\left(p K_{b}=2.74^{32}\right)$ was much less active. Unexpectedly, the catalytic system with $\mathrm{N}$-methylpiperazine showed no activity, probably due to catalyst deactivation. In fact, the reaction of $\left[\mathrm{Rh}\left\{\mathrm{Ph}_{2} \mathrm{P}\left(\mathrm{CH}_{2}\right)_{3} \mathrm{OEt}\right\}_{2}\right]^{+}(\mathbf{5})$ with 1 equiv. of $\mathrm{N}$ methylpiperazine afforded the compound $\left[\mathrm{Rh}\left\{\square \mathrm{Ph}_{2} \mathrm{P}\left(\mathrm{CH}_{2}\right)_{3} \mathrm{OEt}\right\}_{2}\left(\mathrm{~N}_{2} \mathrm{C}_{5} \mathrm{H}_{12}\right)\right]^{+}$(13) that was isolated as a yellow solid in $78 \%$ yield (Scheme 5). The ${ }^{31} \mathrm{P}\left\{{ }^{1} \mathrm{H}\right\}$ NMR of $\mathbf{1 3}$ features two doublet of doublets at $\delta 41.61\left(J_{\mathrm{P}-\mathrm{Rh}}=228.1 \mathrm{~Hz}\right)$ and $40.12 \mathrm{ppm}\left(J_{\mathrm{P}-\mathrm{Rh}}=220.6 \mathrm{~Hz}\right)$ and a $J_{\mathrm{P}-\mathrm{P}}$ of $54.3 \mathrm{~Hz}$. The chelating coordination of the $\mathrm{N}$-methylpiperazine ligand, that drives a change of the coordination mode of the phosphine ligands to $\kappa^{1}-\mathrm{P}, \mathrm{O}$, is the responsible for the inequivalence of the phosphine ligands. Therefore, the great stability of $\mathbf{1 3}$ precludes the formation of any active amido complexes and consequently the compound is inactive. 
Table 3. Anti-Markovnikov oxidative amination of vinylarenes with secondary amines catalysed by $5^{[a]}$

\begin{tabular}{|c|c|c|c|c|c|}
\hline & amine & R" & $t[\mathrm{~h}]$ & $\operatorname{Conv}[\%]^{[\mathrm{b}]}$ & Selec. ${ }^{[\mathrm{c}]}$ \\
\hline 1 & piperidine & $p-\mathrm{Me}$ & 2 & 94 & $95: 5$ \\
\hline 2 & piperidine & $m-\mathrm{Me}$ & 3 & 95 & $94: 6$ \\
\hline 3 & piperidine & $o-\mathrm{Me}$ & 7 & 72 & $93: 7$ \\
\hline 4 & piperidine & $p-{ }^{t} \mathrm{Bu}$ & 6 & 58 & 91:9 \\
\hline 5 & piperidine & $p-\mathrm{CF}_{3}$ & 11 & 64 & $89: 11$ \\
\hline 6 & piperidine & $p$-OMe & 8 & 79 & $94: 6$ \\
\hline 7 & morpholine & $\mathrm{H}$ & 1 & 84 & $95: 5$ \\
\hline 8 & pyrrolidine & $\mathrm{H}$ & 2 & 5 & 100:0 \\
\hline 9 & $\mathrm{Et}_{2} \mathrm{NH}$ & $\mathrm{H}$ & 2 & 11 & 100:0 \\
\hline & $\mathrm{Et}_{2} \mathrm{NH}$ & $\mathrm{H}$ & 8 & 87 & 100:0 \\
\hline 10 & $n \mathrm{Bu}_{2} \mathrm{NH}$ & $\mathrm{H}$ & 6 & 85 & 100:0 \\
\hline
\end{tabular}

[a] Reaction conditions: styrene $(4 \mathrm{mmol})$, piperidine $(1 \mathrm{mmol})$, solvent $(2.5 \mathrm{~mL})$, $[\mathrm{Rh}]=0.01 \mathrm{M}$ in THF, $80^{\circ} \mathrm{C}$. [b] Standard conditions of analysis. Conversion relative to the piperidine (\%) determined by GC analysis using tetradadecane as internal standard. [c] Selectivity: enamine/amine ratio.

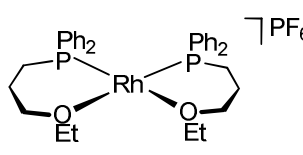

5

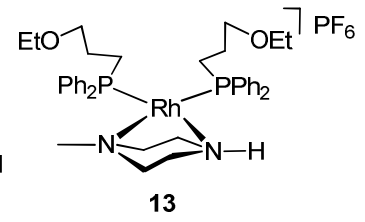

13
Scheme 5

The catalytic systems based on acyclic secondary amines were much less active in the oxidative amination of styrene. However, conversions higher than $85 \%$ can be typically reached in $6-8 \mathrm{~h}$ for $\mathrm{Et}_{2} \mathrm{NH}$ and $\mathrm{n}-\mathrm{Bu}_{2} \mathrm{NH}$ (entries 9 and 10 ). Interestingly, a complete selectivity to the enamine product was observed in spite of the long reaction times required to get acceptable conversions. The catalytic system based on $i-\mathrm{Pr}_{2} \mathrm{NH}$ showed no activity probably as a consequence of the steric effects. ${ }^{33}$

\section{Conclusions}

The mechanism of the anti-Markovnikov oxidative amination of styrene with piperidine catalysed by cationic rhodium(I) complexes containing P,O-functionalized arylphosphine ligands has been investigated by spectroscopic means under stoichiometric and catalytic conditions. Reactivity studies on the catalyst precursor $\left[\mathrm{Rh}\left\{\mathrm{\kappa}^{2}-\mathrm{P}, \mathrm{O}-\mathrm{Ph}_{2} \mathrm{P}\left(\mathrm{CH}_{2}\right)_{3} \mathrm{OEt}\right\}_{2}\right]^{+}$(5) indicate that the reaction proceeds by an amine activation mechanism through the piperidine intermediate species $\left[\mathrm{Rh}\left\{\kappa^{1}-\mathrm{P}-\mathrm{Ph}_{2} \mathrm{P}\left(\mathrm{CH}_{2}\right)_{3} \mathrm{OEt}\right\}_{2}\right.$ $\left.\left(\mathrm{HNC}_{5} \mathrm{H}_{10}\right)\right]_{2}\left[\mathrm{PF}_{6}\right](8)$ which in the presence of piperidine and under thermal conditions is transformed into a neutral amido species with formation of piperidonium cation $\left[\mathrm{H}_{2} \mathrm{NC}_{5} \mathrm{H}_{10}\right]^{+}$. The identity of this neutral amido-piperidine species as $\left[\mathrm{Rh}\left\{\kappa^{1}-\mathrm{P}-\right.\right.$
$\left.\left.\mathrm{Ph}_{2} \mathrm{P}\left(\mathrm{CH}_{2}\right)_{3} \mathrm{OEt}\right\}_{2}\left(\mathrm{NC}_{5} \mathrm{H}_{10}\right)\left(\mathrm{HNC}_{5} \mathrm{H}_{10}\right)\right](9)$ has been established by DFT calculations. The optimization of the structure of $\mathbf{9}$, with an endo disposition of the $\mathrm{NH}$ proton relative to the amido ligand, resulted in a net stabilization of $-12.11 \mathrm{Kcal} \mathrm{mol}^{-1}$ relative to the molecule with a structure $\left[\mathrm{Rh}\left\{\mathrm{Ph}_{2} \mathrm{P}\left(\mathrm{CH}_{2}\right)_{3} \mathrm{OEt}\right\}_{2}\left(\mathrm{NC}_{5} \mathrm{H}_{10}\right)\right]$, having one of the hemilabile phosphine ligands $\kappa^{2}-\mathrm{P}, \mathrm{O}$ coordinated and the other $\kappa^{1}$-P-coordinated, as a consequence of $\mathrm{NH}^{\cdots \cdots} \mathrm{N}$ hydrogen bond. NMR studies carried out in the presence of styrene under catalytic conditions showed that $\mathbf{9}$ is a key species in the catalytic oxidative amination of styrene. Related cyclooctadiene-containing catalyst precursors $\left[\mathrm{Rh}(\mathrm{cod})\left\{\kappa^{1}-\mathrm{P}-\mathrm{Ph}_{2} \mathrm{P}\left(\mathrm{CH}_{2}\right)_{3} \mathrm{OEt}\right\}_{\mathrm{n}}\right]^{+}(\mathrm{n}=1,2)$ also gave 9 under the same conditions which suggest that the oxidative amination of the diene ligand in these precursors could be a requirement for the generation of the active catalytic species and, that most probably, their different catalytic activity is related with the concentration of this species.

The catalytic cycle has been thoroughly studied by a series of DFT calculations disclosing the most plausible intermediates. In addition, the transition states of the key steps have been found and characterized. The first step of the proposed mechanism is the replacement of the piperidine ligand in 9 by styrene to give the catalytic active species $\left[\mathrm{Rh}\left\{\kappa^{1}-\mathrm{P}-\mathrm{Ph}_{2} \mathrm{P}\left(\mathrm{CH}_{2}\right)_{3} \mathrm{OEt}\right\}_{2}\left(\mathrm{NC}_{5} \mathrm{H}_{10}\right)\right.$ (styrene)]. The catalytic cycle takes place in two stages. The first stage leads to the oxidative amination of styrene and is followed a concomitant styrene hydrogenation stage, which closes the cycle. The most energetically demanding step of the styrene amination stage is the amido insertion into the coordinated styrene ligand. This step is followed by a facile B-elimination process, which gives the styrilpyperidine reaction product after coordination of piperidine or styrene to the resulting hydrido complex. Thus, two alternate paths for the second stage of the catalytic cycle are possible. The coordination of piperidine should be followed by an oxidative addition step of the $\mathrm{NH}$ group to the rhodium atom. However, a relevant aspect of the whole catalytic cycle is that this $\mathrm{NH}$ oxidative addition step is more energetically demanding than the alternate, operating, mechanism which regenerates the catalytic active amido species via a direct proton transfer from a coordinated piperidine ligand to an alkyl group which is formed after styrene coordination to the hydrido complex.

The optimized structures of the key intermediates in the catalytic cycle have shown that the relative cis arrangement of the functionalized phosphine ligands allows for a $\pi-\pi$ intramolecular interaction between two phenyl groups. This interaction provides a rigid scaffold that directs both hemilabile arms towards the same side of the molecular plane facilitating the protection of the accessible coordination sites at the rhodium centre. As a consequence, the observed hemilabile effect could be related with the stabilization of polar species in solution or unsaturated catalytic intermediates by transient O-coordination.

\section{Experimental Section}

General information. Reactions were carried out under exclusion of air by using standard Schlenk techniques. Solvents were dried by known procedures and distilled under argon just prior to use, or obtained from a Solvent Purification System (Innovative Technologies). $\mathrm{CDCl}_{3}, \mathrm{CD}_{2} \mathrm{Cl}_{2}$, THF- $d_{8}$ (Euriso-top) were dried using activated molecular sieves. The functionalized hemilabile phosphine, $\mathrm{Ph}_{2} \mathrm{P}\left(\mathrm{CH}_{2}\right)_{3} \mathrm{OEt},{ }^{17}$ and catalyst precursors $\mathbf{1 - 6}^{15}$ were prepared following published methods (see supporting information).

Reaction of $\left[\mathrm{Rh}\left\{\square \kappa^{2}-\mathrm{PO}-\mathrm{Ph}_{2} \mathrm{P}\left(\mathrm{CH}_{2}\right)_{3} \mathrm{OEt}\right\}_{2}\right]\left[\mathrm{PF}_{6}\right]$ with piperidine: formation of $\left[R h\left\{\kappa^{1}-\mathbf{P}-P_{2} \mathbf{P}\left(\mathrm{CH}_{2}\right)_{3} \mathrm{OEt}\right\}\left\{\square \kappa^{2}-\mathbf{P O}-\mathrm{Ph}_{2} \mathbf{P}\left(\mathrm{CH}_{2}\right)_{3} \mathrm{OEt}\right\}\left(\mathrm{HNC}_{5} \mathrm{H}_{10}\right)\right]\left[\mathrm{PF}_{6}\right]$ (7). To a solution of $\left[\mathrm{Rh}\left\{\square \kappa^{2}-\mathrm{PO}-\mathrm{Ph}_{2} \mathrm{P}\left(\mathrm{CH}_{2}\right)_{3} \mathrm{OEt}\right\}_{2}\right]\left[\mathrm{PF}_{6}\right]$ (5) $(16.0 \mathrm{mg}, 0.02 \mathrm{mmol})$ in 
tetrahydrofuran- $d_{8}(0.5 \mathrm{~mL}$, in NMR tube) at room temperature, piperidine $(2.00 \mu \mathrm{L}$, $0.02 \mathrm{mmol})$ was added to give an orange solution of 7 . ${ }^{1} \mathrm{H}$ NMR $\left(253 \mathrm{~K}\right.$, THF- $\left.d_{8}\right)$ : $\delta$ 8.35-6.59 (m, 20H, Ph), 4.42, 4.07 (br s, $2 \mathrm{H}, \mathrm{CH}_{2} \mathrm{O}$ ), 3.46 (q, $4 \mathrm{H}, J_{\mathrm{H}-\mathrm{H}}=6.9, \mathrm{CH}_{2} \mathrm{CH}_{3}$ ), $3.43\left(\mathrm{q}, 4 \mathrm{H}, J_{\mathrm{H}-\mathrm{H}}=6.8, \mathrm{CH}_{2} \mathrm{CH}_{3}\right), 3.31\left(\right.$ br s, $\left.1 \mathrm{H}, \mathrm{CH}_{2} \mathrm{O}\right), 3.31-1.99\left(\mathrm{~m}, 8 \mathrm{H}, 4 \mathrm{H} \mathrm{CH}_{2}\right.$ pip + 4H CH $\left.\mathrm{H}_{2}\right), 1.76-1.17\left(\mathrm{~m}, 4 \mathrm{H}, \mathrm{CH}_{2}\right.$ pip, $\left.4 \mathrm{H} \mathrm{CH}_{2}\right), 1.19\left(\mathrm{t}, 6 \mathrm{H}, J_{\mathrm{H}-\mathrm{H}}=7.2, \mathrm{CH}_{2} \mathrm{CH}_{3}\right)$, $1.14\left(\mathrm{t}, 6 \mathrm{H}, J_{\mathrm{H}-\mathrm{H}}=6.9, \mathrm{CH}_{2} \mathrm{CH}_{3}\right), 0.74$ (br s, $1 \mathrm{H}, \mathrm{CH}_{2}$ pip), 0.38 (br, $1 \mathrm{H}, \mathrm{CH}_{2}$ pip). ${ }^{31} \mathrm{P}\left\{{ }^{1} \mathrm{H}\right\}$ RMN $\left(253 \mathrm{~K}, \mathrm{THF}-d_{8}\right): \delta 50.24\left(\mathrm{dd}, J_{\mathrm{P}-\mathrm{Rh}}=215.0, J_{\mathrm{P}-\mathrm{P}}=54.4\right), 30.23\left(\mathrm{dd}, J_{\mathrm{P}-\mathrm{Rh}}\right.$ $\left.=161.0, J_{\mathrm{P}-\mathrm{P}}=54.5\right) .{ }^{13} \mathrm{C}\left\{{ }^{1} \mathrm{H}\right\}$ RMN $\left(253 \mathrm{~K}, \mathrm{THF}-d_{8}\right): \delta 137.34\left(\mathrm{~d}, J_{\mathrm{C}-\mathrm{P}}=47.0, \mathrm{C}_{\mathrm{i}}\right)$, $135.33\left(\mathrm{~d}, J_{\mathrm{C}-\mathrm{P}}=46.9, \mathrm{C}_{\mathrm{i}}\right), 132.23-128.28\left(\mathrm{C}_{\mathrm{o}}, \mathrm{C}_{\mathrm{p}}, \mathrm{C}_{\mathrm{m}}\right), 70.72\left(\mathrm{CH}_{2} \mathrm{CH}_{3}\right), 69.83\left(\mathrm{CH}_{2} \mathrm{O}\right)$ $68.61\left(\mathrm{CH}_{2} \mathrm{O}\right), 65.94\left(\mathrm{CH}_{2} \mathrm{CH}_{3}\right), 48.87,48.56\left(\mathrm{CH}_{2} \mathrm{pip}\right), 29.15\left(\mathrm{CH}_{2}\right), 27.61\left(\mathrm{CH}_{2} \mathrm{pip}\right)$ $26.90\left(\mathrm{CH}_{2}\right), 24.04,24.19\left(\mathrm{CH}_{2}\right.$ pip), 22.26, $20.28\left(\mathrm{CH}_{2}\right), 14.90,12.69\left(\mathrm{CH}_{2} \mathrm{CH}_{3}\right)$. $\mathrm{MS} / \mathrm{ESI}^{+}(\mathrm{MeOH}, \mathrm{m} / \mathrm{z}): 731\left([\mathrm{M}]^{+}\right)$

Reaction of $\left[\mathrm{Rh}\left\{\square \kappa^{2}-\mathrm{PO}-\mathrm{Ph}_{2} \mathrm{P}\left(\mathrm{CH}_{2}\right)_{3} \mathrm{OEt}\right\}_{2}\right]\left[\mathrm{PF}_{6}\right]$ (5) with piperidine in excess: formation of $\left[\mathrm{Rh}\left\{\boldsymbol{\kappa}^{1}-\mathrm{P}-\mathrm{Ph}_{2} \mathbf{P}\left(\mathrm{CH}_{2}\right)_{3} \mathrm{OEt}\right\}_{2}\left(\mathrm{HNC}_{5} \mathrm{H}_{10}\right)_{2}\right]\left[\mathrm{PF}_{6}\right](\mathbf{8})$. To a solution of $\left[\mathrm{Rh}\left\{\square \kappa^{2}-\mathrm{PO}-\mathrm{Ph}_{2} \mathrm{P}\left(\mathrm{CH}_{2}\right)_{3} \mathrm{OEt}\right\}_{2}\right]\left[\mathrm{PF}_{6}\right](5)(16.0 \mathrm{mg}, 0.02 \mathrm{mmol})$ in tetrahydrofuran- $d_{8}$ $(0.5 \mathrm{~mL}$, in NMR tube) at room temperature, an excess of piperidine $(8.00 \mu \mathrm{L}, 0.08$ mmol) was added. The colour of the solution immediately changed to orange due to the formation of 8. ${ }^{1} \mathrm{H}$ RMN (193 K, THF- $\left.d_{8}\right): \delta$ 7.89-7.16 (m, 20H, Ph), $3.37(\mathrm{q}, 4 \mathrm{H}$, $J_{\mathrm{H}-\mathrm{H}}=6.9, \mathrm{CH}_{2} \mathrm{CH}_{3}$ ), $3.34\left(\mathrm{br} \mathrm{s}, 4 \mathrm{H}, \mathrm{CH}_{2} \mathrm{O}\right), 3.14\left(\mathrm{~m}, 2 \mathrm{H}, \mathrm{CH}_{2}\right.$ pip), $2.91\left(\mathrm{t}, 2 \mathrm{H}, J_{\mathrm{H}-\mathrm{H}}=\right.$ 11.0, $\mathrm{CH}_{2}$ pip), $2.84\left(\mathrm{~m}, 2 \mathrm{H}, \mathrm{CH}_{2}\right.$ pip), 2.49 (t, $2 \mathrm{H}, J_{\mathrm{H}-\mathrm{H}}=11.0, \mathrm{CH}_{2}$ pip), $2.04(\mathrm{~m}, 2 \mathrm{H}$ $\mathrm{CH}_{2}$ pip), 1.92 (br s, $4 \mathrm{H}, \mathrm{CH}_{2}$ ), 1.69 (br s, $2 \mathrm{H}, \mathrm{CH}_{2}$ pip), $1.50-1.32$ (m, $8 \mathrm{H}, 4 \mathrm{H} \mathrm{CH}_{2}$ pip $+2 \mathrm{H} \mathrm{CH}_{2}$ pip $\left.+4 \mathrm{H} \mathrm{CH}_{2}\right), 1.16\left(6 \mathrm{H}, \mathrm{t}, J_{\mathrm{H}-\mathrm{H}}=7.0, \mathrm{CH}_{2} \mathrm{CH}_{3}\right), 0.42\left(\mathrm{CH}_{2}\right.$ pip $)$. ${ }^{31} \mathrm{P}\left\{{ }^{1} \mathrm{H}\right\}$ RMN $\left(193 \mathrm{~K}, \mathrm{THF}-d_{8}\right): \delta 38.29\left(\mathrm{~d}, J_{\mathrm{P}-\mathrm{Rh}}=170.2\right) .{ }^{13} \mathrm{C}\left\{{ }^{1} \mathrm{H}\right\} \mathrm{RMN}(193 \mathrm{~K}$, THF- $\left.d_{8}\right): \delta 136.52\left(\mathrm{~d}, J_{\mathrm{C}-\mathrm{P}}=44.3, \mathrm{C}_{\mathrm{i}}\right), 132.69-129.00(\mathrm{~m}, \mathrm{Ph}), 70.62\left(\mathrm{CH}_{2} \mathrm{O}\right), 66.04$ $\left(\mathrm{CH}_{2} \mathrm{CH}_{3}\right), 50.26\left(\mathrm{CH}_{2}\right.$ pip $), 46.71\left(\mathrm{CH}_{2} \mathrm{pip}\right), 27.95\left(\mathrm{CH}_{2} \mathrm{pip}\right), 27.49\left(\mathrm{CH}_{2} \mathrm{P}\right), 26.30$ ( $\mathrm{CH}_{2}$ pip), $25.01\left(\mathrm{CH}_{2}\right.$ pip $), 23.76\left(\mathrm{CH}_{2}\right), 15.13\left(\mathrm{CH}_{2} \mathrm{CH}_{3}\right)$.

In-situ preparation of $\left[\mathrm{Rh}\left\{\boldsymbol{\kappa}^{1}-\mathrm{P}-\mathrm{Ph}_{2} \mathrm{P}\left(\mathrm{CH}_{2}\right)_{3} \mathrm{OEt}\right\}_{2}\left(\mathrm{NC}_{5} \mathrm{H}_{10}\right)\left(\mathrm{HNC}_{5} \mathrm{H}_{10}\right)\right]$ (9). $\left[\mathrm{Rh}\left\{\square \kappa^{2}-\mathrm{PO}-\mathrm{Ph}_{2} \mathrm{P}\left(\mathrm{CH}_{2}\right)_{3} \mathrm{OEt}\right\}_{2}\right]\left[\mathrm{PF}_{6}\right](\mathbf{5})(0.020 \mathrm{mmol})$ was reacted with piperidine $(0.060 \mathrm{mmol})$ in tetrahydrofuran- $d_{8}(0.5 \mathrm{~mL}$, in a NMR tube $)$. The solution, that contain a mixture of $\mathbf{7}$ and $\mathbf{8}$, was heated at $343 \mathrm{~K}$ for $2 \mathrm{~h} .{ }^{1} \mathrm{H}$ NMR evidence the formation of 9 and $\left[\mathrm{H}_{2} \mathrm{NC}_{5} \mathrm{H}_{10}\right]^{+}$. Data for 9: ${ }^{1} \mathrm{H}$ RMN $\left(298 \mathrm{~K}, \mathrm{THF}-d_{8}\right)$ : $\delta$ 7.53-7.35 $(\mathrm{m}, 20 \mathrm{H}, \mathrm{Ph}), 3.87$ (br s, $1 \mathrm{H}, \mathrm{CH}_{2}$ amido), 3,59 (br s, $2 \mathrm{H}, \mathrm{CH}_{2} \mathrm{O}$ ), 3.42 (q, $2 \mathrm{H}, J_{\mathrm{H}-\mathrm{H}}=$ $\left.7.2, \mathrm{CH}_{2} \mathrm{CH}_{3}\right), 3.36\left(\mathrm{q}, 2 \mathrm{H}, J_{\mathrm{H}-\mathrm{H}}=7.0, \mathrm{CH}_{2} \mathrm{CH}_{3}\right), 3.25\left(\right.$ br s, $\left.2 \mathrm{H}, \mathrm{CH}_{2} \mathrm{O}\right), 3.09$ (br s, $1 \mathrm{H}$, $\mathrm{CH}_{2}$ amido), 3.01 (br s, $1 \mathrm{H}, \mathrm{CH}_{2}$ amido), 2.85 (s, $\mathrm{CH}_{2}$ ), 2.44, 2.43, 2.28, 1.98, 1.97 (br s, $1 \mathrm{H}$ each, $\mathrm{CH}_{2}$ amido), 1.81 (br s, $\left.2 \mathrm{H}, \mathrm{CH}_{2} \mathrm{P}\right), 1.78$ (br s, $\left.2 \mathrm{H}, \mathrm{CH}_{2}\right), 1.57\left(\mathrm{~s}, \mathrm{CH}_{2}\right.$ ), 1.55 (br s, $1 \mathrm{H}, \mathrm{CH}_{2}$ amido), 1.40 (br s, $1 \mathrm{H}, \mathrm{CH}_{2}$ amido), 1.34 (br s, $2 \mathrm{H}, \mathrm{CH}_{2} \mathrm{P}$ ), 1.27 (br s, $\left.2 \mathrm{H}, \mathrm{CH}_{2}\right), 1.12\left(\mathrm{t}, 3 \mathrm{H}, J_{\mathrm{H}-\mathrm{H}}=7.0, \mathrm{CH}_{2} \mathrm{CH}_{3}\right), 1.10\left(\mathrm{t}, 3 \mathrm{H}, J_{\mathrm{H}-\mathrm{H}}=7.5, \mathrm{CH}_{2} \mathrm{CH}_{3}\right)$ ${ }^{31} \mathrm{P}\left\{{ }^{1} \mathrm{H}\right\} \mathrm{RMN}\left(298 \mathrm{~K}, \mathrm{THF}-d_{8}\right): \delta 39.60\left(\mathrm{dd}, J_{\mathrm{P}-\mathrm{Rh}}=165.0, J_{\mathrm{P}-\mathrm{P}}=51.3\right), 36.31\left(\mathrm{dd}, J_{\mathrm{P}-}\right.$ $\left.\mathrm{Rh}=173.1, J_{\mathrm{P}-\mathrm{P}}=51.3\right) .{ }^{13} \mathrm{C}\left\{{ }^{1} \mathrm{H}\right\} \mathrm{RMN}\left(298 \mathrm{~K}, \mathrm{THF}-d_{8}\right): \delta 131.28-127.89(\mathrm{~m}, \mathrm{Ph})$, $70.52\left(\mathrm{~d}, J_{\mathrm{CP}}=13.4, \mathrm{CH}_{2} \mathrm{O}\right), 70.38\left(\mathrm{~d}, \mathrm{~J}_{\mathrm{C}-\mathrm{P}}=13.6, \mathrm{CH}_{2} \mathrm{O}\right), 69.94\left(\mathrm{~d}, \mathrm{CH}_{2} \mathrm{CH}_{3}\right), 65.61$ $\left(\mathrm{CH}_{2} \mathrm{CH}_{3}\right), 53.28,49.40\left(\mathrm{CH}_{2}\right.$ amido $), 29.53\left(\mathrm{~d}, J_{\mathrm{C}-\mathrm{P}}=25.9, \mathrm{CH}_{2} \mathrm{P}\right), 29.40\left(\mathrm{CH}_{2}\right.$ amido $)$, $27.42\left(\mathrm{~d}, J_{\mathrm{C}-\mathrm{P}}=20.9, \mathrm{CH}_{2} \mathrm{P}\right), 26.11\left(\mathrm{CH}_{2}\right), 25.92\left(\mathrm{CH}_{2}\right.$ amido $), 24.49\left(\mathrm{CH}_{2}\right), 23.86$ $\left(\mathrm{CH}_{2}\right.$ amido), $22.22\left(\mathrm{~d}, J_{\mathrm{C}-\mathrm{P}}=14.5, \mathrm{CH}_{2}\right), 22.20\left(\mathrm{~d}, J_{\mathrm{C}-\mathrm{P}}=17.3, \mathrm{CH}_{2}\right), 14.65\left(\mathrm{CH}_{2} \mathrm{CH}_{3}\right)$, $14.59\left(\mathrm{CH}_{2} \mathrm{CH}_{3}\right)$. Data for $\left[\mathbf{H}_{2} \mathbf{N C}_{5} \mathbf{H}_{10}\right]^{+}:{ }^{1} \mathrm{H}$ RMN $\left(298 \mathrm{~K}\right.$, THF- $\left.d_{8}\right): 4.38(\mathrm{br}, 2 \mathrm{H}$, $\left.\mathrm{NH}_{2}{ }^{+}\right), 2.85\left(\mathrm{~s}, \mathrm{CH}_{2}\right), 1.57\left(\mathrm{~s}, \mathrm{CH}_{2}\right) .{ }^{13} \mathrm{C}\left\{{ }^{1} \mathrm{H}\right\}$ RMN $\left(298 \mathrm{~K}, \mathrm{THF}-d_{8}\right): \delta 46.61,26.11$, $24.49\left(\mathrm{CH}_{2}\right)$.

Reaction of $\left[\mathrm{Rh}(\operatorname{cod})\left\{\boldsymbol{\kappa}^{2}-P, O-\mathrm{Ph}_{2} \mathrm{P}\left(\mathrm{CH}_{2}\right)_{3} \mathrm{OEt}\right\}\right]\left[\mathrm{BF}_{4}\right] \quad(1)$ with piperidine. Piperidine $(2 \mu \mathrm{l}, 0.02 \mathrm{mmol})$ was added at room temperature to a solution of $\mathbf{1}(11.40$ $\mathrm{mg}, 0.02 \mathrm{mmol})$ in THF- $d_{8}(0.5 \mathrm{~mL}$, NMR tube). Spectroscopic NMR analysis showed the formation of an equimolar mixture of $\left[\mathrm{Rh}(\operatorname{cod})\left\{\square \kappa^{1}-P-\mathrm{Ph}_{2} \mathrm{P}\left(\mathrm{CH}_{2}\right)_{3} \mathrm{OEt}\right\}_{2}\right]\left[\mathrm{BF}_{4}\right](3)$ and $\left[\mathrm{Rh}(\operatorname{cod})\left(\mathrm{HNC}_{5} \mathrm{H}_{10}\right)_{2}\right]\left[\mathrm{BF}_{4}\right](\mathbf{1 0})$. Data for 10: ${ }^{1} \mathrm{H}$ RMN $\left(298 \mathrm{~K}, \mathrm{THF}-d_{8}\right): 4.03(\mathrm{br}$, $4 \mathrm{H},=\mathrm{CH}$ cod), 2.80 (br s, $4 \mathrm{H}, \mathrm{CH}_{2}$ pip), 2.41-2.33 (m, 8H, $\mathrm{CH}_{2} \mathrm{cod}$ ), 1.79-1.56 (br m, $6 \mathrm{H}, \mathrm{CH}_{2}$ pip). ${ }^{13} \mathrm{C}\left\{{ }^{1} \mathrm{H}\right\}$ RMN $\left(298 \mathrm{~K}\right.$, THF- $\left.d_{8}\right): 81.19$ (br d, $J_{\mathrm{C}-\mathrm{Rh}}=13.2,=\mathrm{CH} \operatorname{cod}$ ), 48.99, $29.86\left(\mathrm{CH}_{2}\right.$ pip), $27.86\left(\mathrm{CH}_{2} \mathrm{cod}\right), 25.84\left(\mathrm{CH}_{2}\right.$ pip$)$.

In-situ preparation of $\left[\mathrm{Rh}(\mathrm{cod})\left\{\mathrm{NC}_{5} \mathrm{H}_{10}\right\}\left\{\mathrm{Ph}_{2} \mathbf{P}\left(\mathrm{CH}_{2}\right)_{3} \mathrm{OEt}\right\}_{2}\right]\left[\mathrm{BF}_{4}\right]$. (11). Piperidine (70 $\mu \mathrm{l}, 0.712$ mmoles) was added to a solution of $\mathbf{3}(15 \mathrm{mg}, 0.018 \mathrm{mmoles})$ in THF- $d_{8}$ ( $0.5 \mathrm{~mL}$, NMR tube). The solution was heated at $333 \mathrm{~K}$ for $20 \mathrm{~min}$., or alternativetely left at $298 \mathrm{~K}$ for $24 \mathrm{~h} .{ }^{1} \mathrm{H}$ RMN (298K, THF- $\left.d_{8}\right): \delta 7.33-7.05$ (m, 20H, Ph), 4.93 (br, $4 \mathrm{H}$, $=\mathrm{CH} \operatorname{cod}), 3.18\left(\mathrm{q}, 4 \mathrm{H}, J_{\mathrm{H}-\mathrm{H}}=7.0, \mathrm{CH}_{2} \mathrm{CH}_{3}\right), 3.08\left(\mathrm{t}, 4 \mathrm{H}, J_{\mathrm{H}-\mathrm{H}}=6.3, \mathrm{CH}_{2} \mathrm{O}\right), 2.85(\mathrm{br} \mathrm{s}$, $2 \mathrm{H}, \mathrm{CH}_{2}$ ), 2.77 (m, 4H, $\mathrm{CH}_{2}$ cod), 1.89 (br s, $4 \mathrm{H}, \mathrm{CH}_{2} \operatorname{cod}$ ), 1.57 (br s, $2 \mathrm{H}, \mathrm{CH}_{2}$ ), 0.97 $\left(\mathrm{t}, 6 \mathrm{H}, J_{\mathrm{H}-\mathrm{H}}=7.0, \mathrm{CH}_{2} \mathrm{CH}_{3}\right) .{ }^{31} \mathrm{P}\left\{{ }^{1} \mathrm{H}\right\} \mathrm{RMN}\left(298 \mathrm{~K}, \mathrm{THF}-d_{8}\right): \delta 30.62\left(\mathrm{~d}, J_{\mathrm{P}-\mathrm{Rh}}=199.5\right)$. ${ }^{13} \mathrm{C}\left\{{ }^{1} \mathrm{H}\right\}$ RMN $\left(298 \mathrm{~K}, \mathrm{THF}-d_{8}\right): \delta 130.52\left(\mathrm{ft}, J_{\mathrm{C}-\mathrm{P}}=5.8, \mathrm{C}_{\mathrm{o}}\right), 125.91\left(\mathrm{C}_{\mathrm{p}}\right), 125.30(\mathrm{ft}$, $\left.J_{\mathrm{C}-\mathrm{P}}=4.2, \mathrm{C}_{\mathrm{m}}\right), \mathrm{C}_{\mathrm{i}}$ (not observed), $100.20\left(\mathrm{~m},=\mathrm{CH}\right.$ cod), $69.32\left(\mathrm{ft}, J_{\mathrm{C}-\mathrm{P}}=7.6, \mathrm{CH}_{2} \mathrm{O}\right)$, $63.72\left(\mathrm{CH}_{2} \mathrm{CH}_{3}\right), 48.01\left(\mathrm{CH}_{2}\right.$ pip), $30.94\left(\mathrm{CH}_{2} \mathrm{cod}\right), 28.00\left(\mathrm{CH}_{2}\right), 27.71\left(\mathrm{CH}_{2} \mathrm{pip}\right)$, $24.22\left(\mathrm{CH}_{2}\right.$ pip), 26.81 (ft, $\left.J_{\mathrm{C}-\mathrm{P}}=13.0, \mathrm{CH}_{2} \mathrm{P}\right), 12.85\left(\mathrm{CH}_{2} \mathrm{CH}_{3}\right)$

Synthesis of $\left[\mathbf{R h}\left\{\boldsymbol{\kappa}^{1}-\mathbf{P}-\mathbf{P h}_{2} \mathbf{P}\left(\mathrm{CH}_{2}\right)_{3} \mathbf{O E t}\right\}_{2}\left(\mathbf{N}_{2} \mathbf{C}_{5} \mathbf{H}_{12}\right)\right]\left[\mathbf{P F}_{6}\right]$ (13). $N$-methylpiperazine $(8.40 \mu \mathrm{L}, \quad 0.088 \mathrm{mmol})$ was added to a solution of $\left[\mathrm{Rh}\left\{\square \kappa^{2}-\mathrm{PO}-\right.\right.$ $\left.\left.\mathrm{Ph}_{2} \mathrm{P}\left(\mathrm{CH}_{2}\right)_{3} \mathrm{OEt}\right\}_{2}\right]\left[\mathrm{PF}_{6}\right](5)(60.0 \mathrm{mg}, 0.088 \mathrm{mmol})$ in tetrahydrofuran $(4 \mathrm{~mL})$ at room temperature and the solution stirred for 1 hour. The volatiles were removed under reduced pressure and the residue disaggregated by washing with cold $n$-hexane $(3 \times 4$ $\mathrm{mL}$ ) at $0{ }^{\circ} \mathrm{C}$ to give a yellow solid. Yield: $78 \%$; elemental analysis of $\mathrm{C}_{39} \mathrm{H}_{54} \mathrm{~N}_{2} \mathrm{~F}_{6} \mathrm{O}_{2} \mathrm{P}_{3} \mathrm{Rh}$ cald (\%): C, 52.47; H, 6.10; N, 3.14; found: C, 52.33; H, 6.25; N, 3.10. MS/FAB ${ }^{+}(\mathrm{m} / \mathrm{z}, \%): 892\left([\mathrm{M}]^{+}, 100\right) .{ }^{1} \mathrm{H}$ NMR $\left(253 \mathrm{~K}\right.$, THF- $\left.d_{8}\right): \delta 7.84-7.31(\mathrm{~m}$ $20 \mathrm{H}, \mathrm{Ph}$ ), 3.55 (br s, $1 \mathrm{H}, \mathrm{CH}_{2}$-amine), 3.52 (br s, $1 \mathrm{H}, \mathrm{CH}_{2}$-amine), 3,38 (m, $9 \mathrm{H}, 4 \mathrm{H}$ $\mathrm{CH}_{2} \mathrm{O}+4 \mathrm{H} \mathrm{CH} \mathrm{CH}_{3}+1 \mathrm{H}-\mathrm{CH}_{2}$-amine), 3.23 (br s, $1 \mathrm{H}, \mathrm{NH}$ ), 2.71 (br s, $1 \mathrm{H}, \mathrm{CH}_{2}-$ amine), 2.42 (br s, $2 \mathrm{H}, \mathrm{CH}_{2} \mathrm{P}$ ), 2.36 (br s, $1 \mathrm{H}, \mathrm{CH}_{2}$-amine), 2.16 (br s, $2 \mathrm{H}, \mathrm{CH}_{2} \mathrm{P}$ ), 2.06 (br s, $1 \mathrm{H}, \mathrm{CH}_{2}$-amine), 2.00 (br s, $1 \mathrm{H}, \mathrm{CH}_{2}$-amine), 1.93 (br s, $2 \mathrm{H}, \mathrm{CH}_{2}$ ), 1.81 (br s, $\left.2 \mathrm{H}, \mathrm{CH}_{2}\right), 1.73$ (br s, $1 \mathrm{H}, \mathrm{CH}_{2}$-amine), $1,70\left(\mathrm{~s}, 3 \mathrm{H}, \mathrm{CH}_{3}\right), 1.12\left(\mathrm{~m}, 6 \mathrm{H}, \mathrm{CH}_{2} \mathrm{CH}_{3}\right)$; ${ }^{31} \mathrm{P}\left\{{ }^{1} \mathrm{H}\right\}$ NMR $\left(253 \mathrm{~K}, \mathrm{THF}-d_{8}\right): \delta 41.61\left(\mathrm{dd}, J_{\mathrm{P}-\mathrm{Rh}}=228.1, J_{\mathrm{P}-\mathrm{P}}=54.3\right), 40.12\left(\mathrm{dd}, J_{\mathrm{P}-\mathrm{Rh}}\right.$ $\left.=220.6 \mathrm{~Hz}, J_{\mathrm{P}-\mathrm{P}}=54.3 \mathrm{~Hz}\right) ;{ }^{13} \mathrm{C}\left\{{ }^{1} \mathrm{H}\right\} \mathrm{NMR}\left(253 \mathrm{~K}, \mathrm{THF}-d_{8}\right): \delta 138.25\left(\mathrm{~d}, J_{\mathrm{C}-\mathrm{P}}=40.6\right.$, $\left.\mathrm{C}_{\mathrm{j}}\right), 136.98\left(\mathrm{~d}, J_{\mathrm{C}-\mathrm{P}}=40.6, \mathrm{C}_{\mathrm{i}}\right), 133.67-129.30(\mathrm{Ph}), 71.65\left(\mathrm{dd}, J_{\mathrm{C}-\mathrm{P}}=16.3, J_{\mathrm{C}-\mathrm{Rh}}=6.3\right.$, $\left.\mathrm{CH}_{2} \mathrm{O}\right), 71.22\left(\mathrm{~d}, \mathrm{~J}_{\mathrm{C}-\mathrm{P}}=15.1, \mathrm{CH}_{2} \mathrm{O}\right), 66.96,66.63\left(\mathrm{CH}_{2} \mathrm{CH}_{3}\right), 57.00\left(\mathrm{NCH}_{2}\right), 48.61$ $\left(\mathrm{NCH}_{3}\right), 46.37,33.15\left(\mathrm{NCH}_{2}\right), 29.09\left(\mathrm{~d}, J_{\mathrm{C}-\mathrm{P}}=4.7, \mathrm{CH}_{2}\right), 27.91\left(\mathrm{NCH}_{2}\right), 27.35\left(\mathrm{~d}, J_{\mathrm{C}-\mathrm{P}}\right.$ $\left.=34.7, \mathrm{CH}_{2} \mathrm{P}\right), 26.13\left(\mathrm{~d}, J_{\mathrm{C}-\mathrm{P}}=29.9, \mathrm{CH}_{2} \mathrm{P}\right), 25.97,24.08\left(\mathrm{CH}_{2} \mathrm{CH}_{3}\right), 23.23\left(\mathrm{~d}, J_{\mathrm{C}-\mathrm{P}}=\right.$ $3.4, \mathrm{CH}_{2}$ ).

General Procedure for Hydroamination Catalytic Experiments. The catalytic hydroamination reactions were carried out under an argon atmosphere in a thick glass reaction tube fitted with a greaseless high-vacuum stopcock. In a typical experiment, the reactor was charged with a solution of the catalyst $(0.020 \mathrm{mmol})$ in THF $\left(2 \mathrm{~cm}^{3}\right), 2$ $\mathrm{mg}$ of molecular sieves in powder $(4 \AA)$ and the reactants in the following order: piperidine $(0.800 \mathrm{mmol}, 79 \mu \mathrm{L})$, tetradecane as internal standard $(0.350 \mathrm{mmol}, 91 \mu \mathrm{L})$ and styrene $(3.24 \mathrm{mmol}, 371 \mu \mathrm{L})$. The mixture was stirred at room temperature until the catalyst was completely dissolved, and then placed in a thermostatized oil bath at the required temperature.

The yield and selectivity were determined by GC HP $6890 \mathrm{~N}$ with an ionization detector fitted up to a HP Ultra- $1(25 \mathrm{~m} \mathrm{x} 0.32 \mathrm{~mm}$ d.i. x $0.17 \mu \mathrm{m})$ under the following conditions: Initial $\mathrm{T}^{\mathrm{a}} 50^{\circ} \mathrm{C}$ for $4 \mathrm{~min}$, ramp $15^{\circ} / \mathrm{min}$, and final $\mathrm{T}^{\mathrm{a}} 250^{\circ}$ for $10 \mathrm{~min}$. Calibration was made with the internal standard tetradecane. Organic compounds were identified by Gas Chromatography-Mass Spectrometry (GC-MS) recorded in the mass range $1-1000 \mathrm{~m} / \mathrm{z}$ on a Agilent $6890 \mathrm{GC}$-Agilent $5973 \mathrm{MS}$, equipped with a polar capillary column HP-5MS (30m x $0.25 \mathrm{~mm}$ d.i. x $0.25 \mu \mathrm{m})$.

Theoretical Calculations Details. All computations were performed using the Gaussian 09 (RevA.02) package. ${ }^{28}$ The structures fully optimized without geometrical constraints and the stationary points (minima and TS) were confirmed by frequency calculations. The connection between the transition states and the minima were checked by visual inspection of the negative frequency calculation and IRC in some cases. The calculations were carried out using the B3LYP functional and the basis sets used were: LANL2DZ and its associated ECP for rhodium and 6-31G** for the rest of atoms. The structures have been depicted using CYLview. ${ }^{34}$

\section{Acknowledgements}

Financial support from the Ministerio de Economía y Competitividad (MINECO/FEDER), projects CTQ2010-15221 and MULTICAT (CSD2009-00050), and Gobierno de Aragón/FSE (Group E07) is gratefully acknowledged. M.I.B. and D.G. thank the Spanish MICINN and the IUCH (Instituto Universitario de Catálisis Homogénea) for a predoctoral fellowship.

\section{References}

[1] a) J.-S. Ryu, G. Y. Li, T. J. Marks, J. Am. Chem. Soc. 2009, 125, 12584 12605 ; b) T. E. Müller, K. C. Hultzsch, M. Yus, F. Foubelo, M. Tada, Chem. Rev. 2008, 108, 3795-3892; c) R. Taube in Applied Homogeneous Catalysis with Organometallic Compounds (Ed.: B. Cornils, W. A. Herrmann), Wiley-VCH, Weinheim, 1996, pp. 513-524

[2] a) A. L. Reznichenko, H. N. Nguyen, K. C. Hultszch, Angew. Chem. Int. Ed. 2010, 49, 8984-8987; b) K.C. Hultzsch, Adv. Synth. Catal., 2005, 347, 367-391; c) J. Y. Kim, T. Livinghouse, Org. Lett. 2005, 7, 1737-1739; d) S. Hong, T. J. Marks, Acc. Chem. Res. 2004, 37, 673-686; e) G. A. Molander, J. A. C. Romero, Chem. Rev. 2002 $102,2161-2185$.

[3] a) N. Hazari, P. Mountford, Acc. Chem. Res. 2005, 38, 839-849; b) F. Pohlki, S. Doye, Chem. Soc. Rev. 2003, 32, 104-114.

[4] a) A. Motta, I. L. Fragalá, T. J. Marks, Organometallics 2006, 25, 5533-4439; b) S. Tobisch, Chem. Eur. J. 2006, 12, 2520-2531; c) M. R. Gagné, T. J. Marks, J. Am Chem. Soc. 1989, 111, 4108-4110.

[5] a) J. A. Bexrud, J. D. Bear, D. C. Leitch, L. L. Schafer, Org. Lett. 2005, 7, 1959-1962; b) B. D. Ward, A. Maisse-François, L. H. Gade, P. Mountford, Chem. Commun. 2004, 704-705; c) Z. K. Sweeney, J. L. Salsman, R. A. Andersen, R. G. Bergman, Angew. Chem. Int. Ed. 2000, 39, 2339-2343.

[6] a) J. Zhang, C. G. Yang, C. He, J. Am. Chem. Soc. 2006, 128, 1798-1799; b) D. Karshtedt, A. T. Bell, T. D. Tilley, J. Am. Chem. Soc. 2005, 127, 12640-12646; c) J. M. Seul, S. Park, J. Chem. Soc., Dalton Trans. 2002, 1153-1158; d) M. Beller, C. Breindl, M. Eichberger, C. G. Hartung, J. Seayad, O. R. Thiel, A. Tillack, H. Trauthwein, Synlett 2002, 1579-1594.

[7] a) Z. Liu, H. Yamamichi, S. T. Madrahimov, J. F. Hartwig, J. Am. Chem. Soc. 2011, 133, 2772-2782; b) K. D. Hesp, S. Tobisch, M. Stradiotto J. Am. Chem. Soc. 2010, 132, 413-426; c) X. Li, A. R. Chianese, T. Vogel, R. H. Crabtree, Org. Lett. 
2005, 7, 5437-5440; d) T. E. Müller, M. Berger, M. Grosche, E. Herdtweck, F. P. Schmidtchen, Organometallics 2001, 20, 4384-4393.

[8] I. Mena, M. A. Casado, P. García-Orduña, V. Polo, F. J. Lahoz, A. Fazal, L. A. Oro, Angew. Chem. Int. Ed. 2011, 50, 1-5.

[9] a) E. Morgan, D. F. MacLean, R. McDonald, L. Turculet, J. Am. Chem. Soc. 2009, 131, 14234-14236; b) J. Zhao, A. S. Goldman, J. F. Hartwig, Science 2005, 307 1080-1082; c) M. S. Driver, J. F. Hartwig, J. Am. Chem. Soc. 1996, 118, 4206-4207; d) M. D. Fryzuk, C. D. Montgomery, Coord. Chem. Rev. 1989, 95, 1-40; e) A. L. Casalnuovo, J. C. Calabrese, D. Milstein, Inorg. Chem. 1987, 26, 971-973.

[10] a) J. W. Tye, J. F. Hartwig, J. Am. Chem. Soc. 2009, 131, 14703-14712; b) P. Zhao, C. Krug, J. F. Hartwig, J. Am. Chem. Soc. 2005, 127, 12066-12073.

[11] R. L. Cowan, W. C. Trogler, J. Am. Chem. Soc. 1989, 111, 4750-4761.

[12] a) D. S. Glueck, L. J. Newman-Winslow, R. G. Bergman, Organometallics 1991, 10, 1462-1479; b) M. S. Driver, J. F. Hartwig, J. Am. Chem. Soc. 1997, 119 , $8232-8245$.

[13] J. -J. Brunet, D. Neibecker, K. Philippot, Tetrahedron Lett. 1993, 34, $3877-$ 3880

[14] M. V. Jiménez, J. J. Pérez-Torrente, M. I. Bartolomé, F. J. Lahoz, L. A. Oro, Chem. Commun. 2010, 46, 5322-5324.

[15] M. V. Jiménez, M. I. Bartolomé, J. J. Pérez-Torrente, F. J. Lahoz, L. A. Oro ChemCatChem 2012, DOI: 10.1002/cctc.201200101.

[16] A. Uhe, M. Hölscher, W. Leitner, Chem. Eur. J. 2010, 16, 9203-9214.

[17] M. V. Jiménez, J. J. Pérez-Torrente, M. I. Bartolomé, L. A. Oro, Synthesis 2009, 11, 1916-1922.

[18] $\mathrm{TOF}_{50}=$ Turnover frequency estimated at $50 \%$ of piperidine conversion.

[19] D. A. Buckingham, C. R. Clark, M. G. Weller, G. J. Gainsford, Chem. Commun. 1982, 779-781.

[20] J. -J. Brunet, C. Commenges, D. Neibecker, K. Philippot, L. Rosenberg, Inorg. Chem. 1994, 33, 6373-6379.

[21] M. Beller, M. Eichberger, H. Trauthwein, Angen. Chem. Int. Ed. Engl. 1997, $36,2225-2227$.

[22] J. W. Tye, J. F. Hartwig, J. Am Chem. Soc. 2009, 131, 14703-14712.

[23] P. Zhao, C. Krug, J. F. Hartwig, J. Am. Chem. Soc. 2005, 127, 12066-12073.

[24] K. D. Hesp, M. Stradiotto, ChemCatChem 2010, 2, 1192-1207.

[25] a) J. M. Brown, G. C. Lloyd-Jones, J. Am. Chem. Soc. 1994, 116, 866-878; b) J. M. Brown, G. C. Lloyd-Jones, J. Chem. Soc., Chem. Commun. 1992, 710-712

[26] M. Beller, H. Trauthwein, M. Eichberger, C. Breindl, J. Herwig, T. E. Müller, O. R. Thiel, Chem. Eur. J. 1999, 5, 1306-1319.

[27] M. Utsunomiya, R. Kuwano, M. Kawatsura, J. F. Hartwig, J. Am. Chem. Soc. 2003, $125,5608-5609$.

[28] Frisch, M. J. et al. Gaussian 09, Revision A.02; Gaussian, Inc., Wallingford, CT, 2009 (see the Supporting Information for complete citation).

[29] X. Yuan, S. Bi, Y. Ding, L. Liu, M. Sun, J. Organomet. Chem. 2010, 695, $1576-1582$.

[30] K. H. Hopmann, J. Conradie, Organometallics 2009, 28, 3710-3715.

[31] K. H. Hopmann, N. F. Stuurman, A. Muller, J. Conradie, Organometallics 2010, 29, 2446-2458.

[32] S. P. Anthony, S. Varughese, S. M. Draper, Chem. Commun. 2009, 7500-7502.

[33] $\mathrm{n}-\mathrm{Bu}_{2} \mathrm{NH}, \mathrm{pKa}$ (benzene) $=10.66 ; \mathrm{i}-\mathrm{Pr}_{2} \mathrm{NH}, \mathrm{pKa}$ (benzene) $=11.13 ; \mathrm{i}-\mathrm{Et}_{2} \mathrm{NH}$, pKa (benzene) $=10.97$; a) J. A. Tayh; R. M. Scott, J. Mol. Struct., 1990 , 237, 297 305; b) M. Abduljaber, R. M. Scott, J. Mol. Struct., 1990, 237, 285 - 295; c) V. Frenna, N. Vivona, G. Consiglio, D. Spinelli, J. Chem. Soc., Perkin Trans. 2, 1985, $1865-1868$

[34] Legault, C. Y., Université de Sherbrooke, 2009 CYLview, 2009 


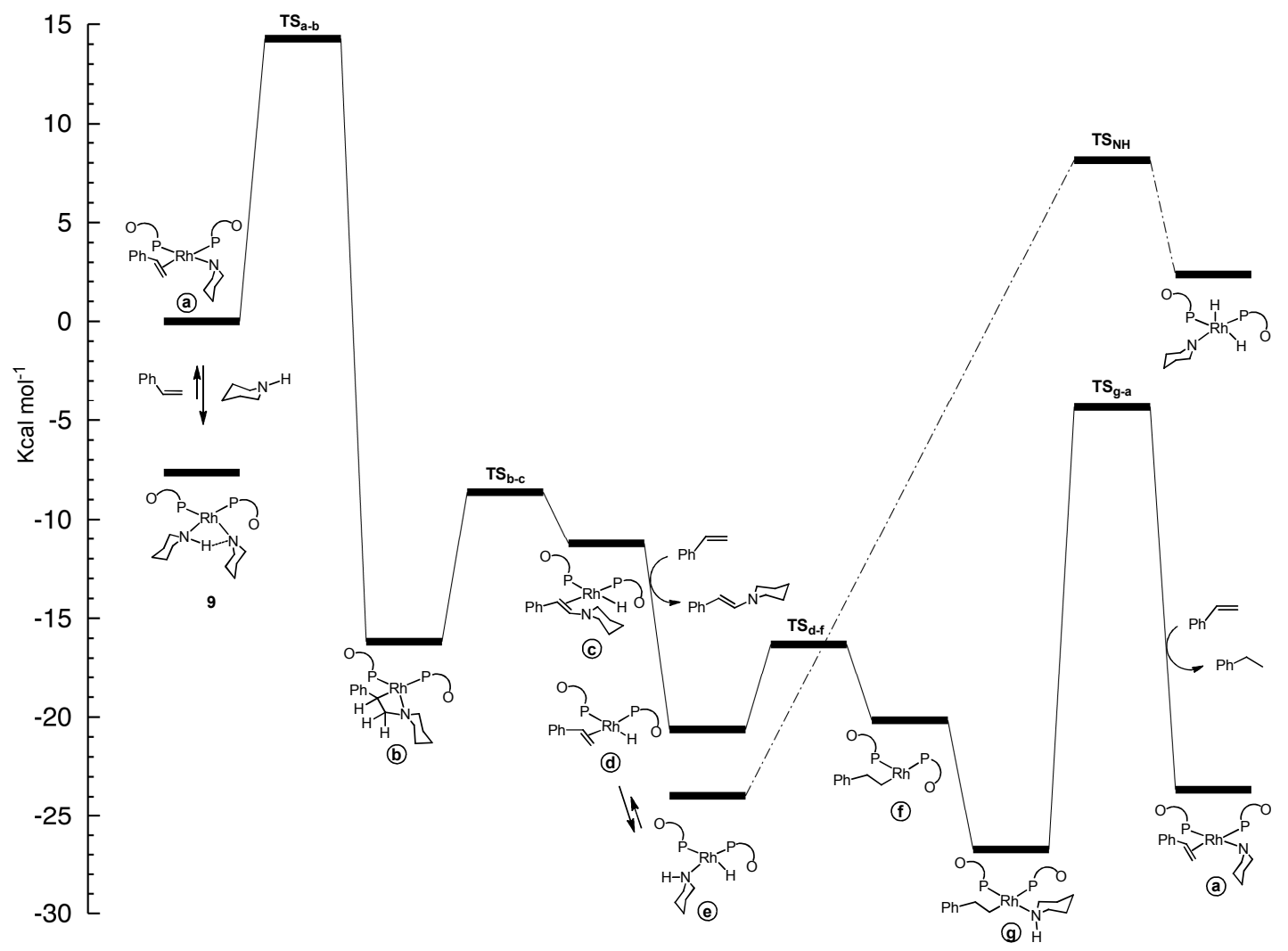

Figure 11. Calculated energy profile for cycle fig. 10 . 
Entry for the Table of Contents (Please choose one layout only)

NH proton transfer vs oxidative addition

M. Victoria Jiménez, * M. Isabel

Bartolomé, Jesús J. Pérez-

Torrente, * Daniel Gómez, F. Javier

Modrego, and Luis A. Oro

Page - Page

Mechanistic Studies on the

Catalytic Oxidative Amination of

Alkenes by Rhodium(I)

Complexes with Hemilabile

Phosphines

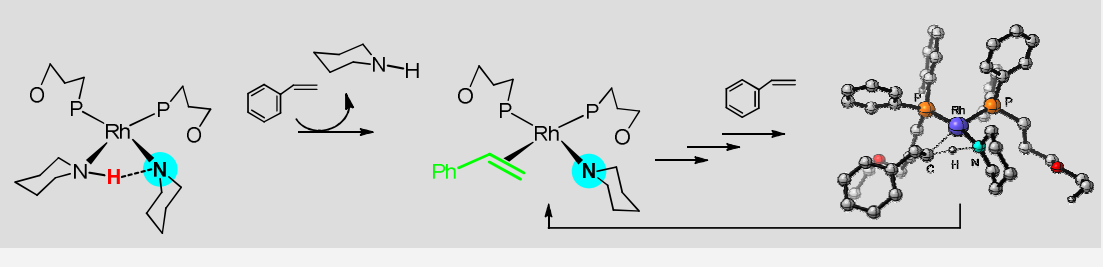

The catalytic active amido species involved in the oxidative amination of styrene with piperidine catalysed by rhodium(I) complexes having P,Ofunctionalized phosphine ligands is regenerated via a direct proton transfer from a coordinated amine to an alkyl group. The alternative $\mathrm{NH}$ oxidative addition pathway leading to a dihydride intermediate is a highly energydemanding process. 